\title{
Frustrated Lewis Pair Stabilized Phosphoryl Nitride (NPO), a Mono Phosphorus Analogue of Nitrous Oxide $\left(\mathrm{N}_{2} \mathrm{O}\right)$
}

André K. Eckhardt, ${ }^{a}$ Martin-Louis Y. Riu, ${ }^{a}$ Peter Müller ${ }^{\mathrm{a}}$ and Christopher C. Cummins ${ }^{\mathrm{a}, *}$

a Department of Chemistry, Massachusetts Institute of Technology, Cambridge, Massachusetts 02139, United States

*ccummins@mit.edu

\section{Table of Contents}

$\begin{array}{ll}\text { General Information } & \text { S2 }\end{array}$

$\begin{array}{ll}\text { Synthesis of } \mathrm{N}_{3} \mathrm{P}(\mathrm{O}) \mathrm{A} & \text { S2 }\end{array}$

Synthesis of $\mathrm{Cy}_{3} \mathrm{P}=\mathrm{NP}(\mathrm{O}) \mathbf{A} \quad$ S6

Synthesis of $\mathrm{Cy}_{3} \mathrm{P}-\mathrm{NP}(\mathbf{A}) \mathrm{O}-\mathrm{B}\left(\mathrm{C}_{6} \mathrm{~F}_{5}\right)_{3} \quad$ S8

$\begin{array}{ll}\text { Synthesis of } \mathrm{Cy}_{3} \mathrm{P}-\mathrm{NPO}-\mathrm{B}\left(\mathrm{C}_{6} \mathrm{~F}_{5}\right)_{3} & \mathrm{~S} 11\end{array}$

$\begin{array}{ll}\text { NMR Decay } \mathrm{N}_{3} \mathrm{P}(\mathrm{O}) \mathbf{A} & \mathrm{S} 15\end{array}$

$\begin{array}{ll}\text { Decay of Solid } \mathrm{N}_{3} \mathrm{P}(\mathrm{O}) \mathbf{A} & \mathrm{S} 18\end{array}$

Molecular Beam Mass Spectrometry (MBMS) $\quad$ S19

$\begin{array}{ll}\text { X-Ray Diffraction Studies } & \text { S20 }\end{array}$

$\begin{array}{ll}\text { Computational Studies } & \text { S25 }\end{array}$

References and Full Citations for Electronic Structure Codes $\quad$ S36 


\section{General Remarks}

All manipulations were performed in a Vacuum Atmospheres model MO-40M glovebox under an inert atmosphere of purified $\mathrm{N}_{2}$. All solvents were obtained anhydrous and oxygen-free by bubble degassing $\left(\mathrm{N}_{2}\right)$ and purification through columns of alumina and $\mathrm{Q} 5,{ }^{1}$ and storage over molecular sieves. ${ }^{2}$ Literature procedures were followed for the preparation of $\mathrm{MgA} \cdot 3 \mathrm{THF},{ }^{3} \mathrm{Me}_{2} \mathrm{NPA},{ }^{4} \mathrm{ClPA},{ }^{4} \mathrm{~N}_{3} \mathrm{PA}(\mathbf{A}=$ $\mathrm{C}_{14} \mathrm{H}_{10}$, anthracene), ${ }^{5}$ and 2,4,6-trimethylbenzonitrile $\mathrm{N}$-oxide (MesCNO). ${ }^{6-7}$ Deuterated solvents were purchased from Cambridge Isotope Labs, degassed, and stored over molecular sieves for at least $48 \mathrm{~h}$ prior to use. Activated Charcoal Norit CA1 (Aldrich) and Celite 435 (EM Science) were dried by heating above $200{ }^{\circ} \mathrm{C}$ under dynamic vacuum for at least $48 \mathrm{~h}$. All glassware was oven dried for at least $3 \mathrm{~h}$ at temperatures greater than $150{ }^{\circ} \mathrm{C}$. NMR spectra were obtained on a Bruker Avance-III HD Nanobay spectrometer operating at $400.09 \mathrm{MHz}$ equipped with a $5 \mathrm{~mm}$ liquid-nitrogen cooled Prodigy broad band observe cryoprobe or on a Bruker Avance Neo spectrometer operating at $500.34 \mathrm{MHz}$ equipped with a $5 \mathrm{~mm}$ liquid-nitrogen cooled Prodigy broad band observe cryoprobe. ${ }^{1} \mathrm{H}$ and ${ }^{13} \mathrm{C}$ NMR spectra were referenced to residual protiated solvent resonances; ${ }^{8}{ }^{31} \mathrm{P}$ NMR spectra were referenced externally to $85 \%$ aqueous $\mathrm{H}_{3} \mathrm{PO}_{4}(\delta=0 \mathrm{ppm})$. Elemental analyses were performed by Midwest Microlab (Indianapolis, IN). High resolution mass spectral (HRMS) data were collected using a Jeol AccuTOF 4G LC-Plus mass spectrometer equipped with an Ion-Sense DART source. Data were calibrated to a sample of PEG-600 and were collected in positive ion. Samples were prepared in THF (ca. $10 \mu \mathrm{M}$ concentration) and were briefly exposed to air $(<5 \mathrm{~s})$ before being placed in front of the DART source.

\section{Synthesis of $\mathrm{N}_{3} \mathrm{P}(\mathrm{O}) \mathrm{A}$}

\section{Attention: Solid $N_{3} P A$ is explosive! $!^{5}$}

Inside the glovebox, a $20 \mathrm{~mL}$ vial was charged with solid, colorless $\mathrm{N}_{3} \mathrm{PA}$ (195 mg, $0.78 \mathrm{mmol}, 1.0$ equiv), 2,4,6-trimethylbenzonitrile $N$-oxide (MesCNO, $125 \mathrm{mg}, 0.78 \mathrm{mmol}, 1$ equiv) and $4 \mathrm{~mL}$ diethyl ether. The solution turned homogeneous after addition of $1 \mathrm{~mL}$ THF within a few minutes and was further stirred for $30 \mathrm{~min}$ at room temperature under aluminum foil in the dark. After adding $15 \mathrm{~mL}$ hexanes, the reaction mixture was placed in the freezer at $-20{ }^{\circ} \mathrm{C}$ for one hour. A colorless precipitate developed, which was filtered and washed with a minimal amount of pentane and further dried in the glovebox in the dark for $30 \mathrm{~min}$. Yields varied depending on how much anthracene was produced during the course of the reaction, giving up to $154 \mathrm{mg}$ (74\%) of clean product. The identity of the product was confirmed by NMR and IR spectroscopy as well as by an X-ray diffraction study performed on a crystal grown from diethyl ether at $-20{ }^{\circ} \mathrm{C}$ (Figure 2). The crystalline compound turns red-brown at $60{ }^{\circ} \mathrm{C}$ and does melt at around $220{ }^{\circ} \mathrm{C}$. DART HRMS(Q-TOF) $m / z$ : $[\mathrm{M}+\mathrm{H}]^{+}$Calcd for $\mathrm{C}_{14} \mathrm{H}_{11} \mathrm{~N}_{3} \mathrm{PO} 268.0634$; Found 268.0648. ${ }^{1} \mathrm{H}$ NMR (benzene- $\left.d_{6}, 400 \mathrm{MHz}, 25{ }^{\circ} \mathrm{C}\right) \delta 7.09(\mathrm{~m}, 2 \mathrm{H}), 6.92(\mathrm{~m}, 6 \mathrm{H}), 4.09(\mathrm{~d}, 2 \mathrm{H}$, 
$\left.{ }^{2} J_{\mathrm{PH}}=11.1 \mathrm{~Hz}\right) \mathrm{ppm} .{ }^{13} \mathrm{C}\left\{{ }^{1} \mathrm{H}\right\}$ NMR (benzene- $\left.d_{6}, 101 \mathrm{MHz}, 25{ }^{\circ} \mathrm{C}\right) \delta 138.3(\mathrm{~d}, J=13.1 \mathrm{~Hz}), 134.3(\mathrm{~d}, J$ $=12.0 \mathrm{~Hz}), 127.2(\mathrm{~d}, J=1.7 \mathrm{~Hz}), 127.1(\mathrm{~d}, J=1.5 \mathrm{~Hz}), 124.2(\mathrm{~d}, J=9.0 \mathrm{~Hz}), 123.3(\mathrm{~d}, J=8.8 \mathrm{~Hz})$, $53.4(\mathrm{~d}, J=69.9 \mathrm{~Hz}) \mathrm{ppm} .{ }^{31} \mathrm{P}\left\{{ }^{1} \mathrm{H}\right\}$ NMR (benzene- $\left.d_{6}, 162 \mathrm{MHz}, 25{ }^{\circ} \mathrm{C}\right) \delta 76 \mathrm{ppm}$.

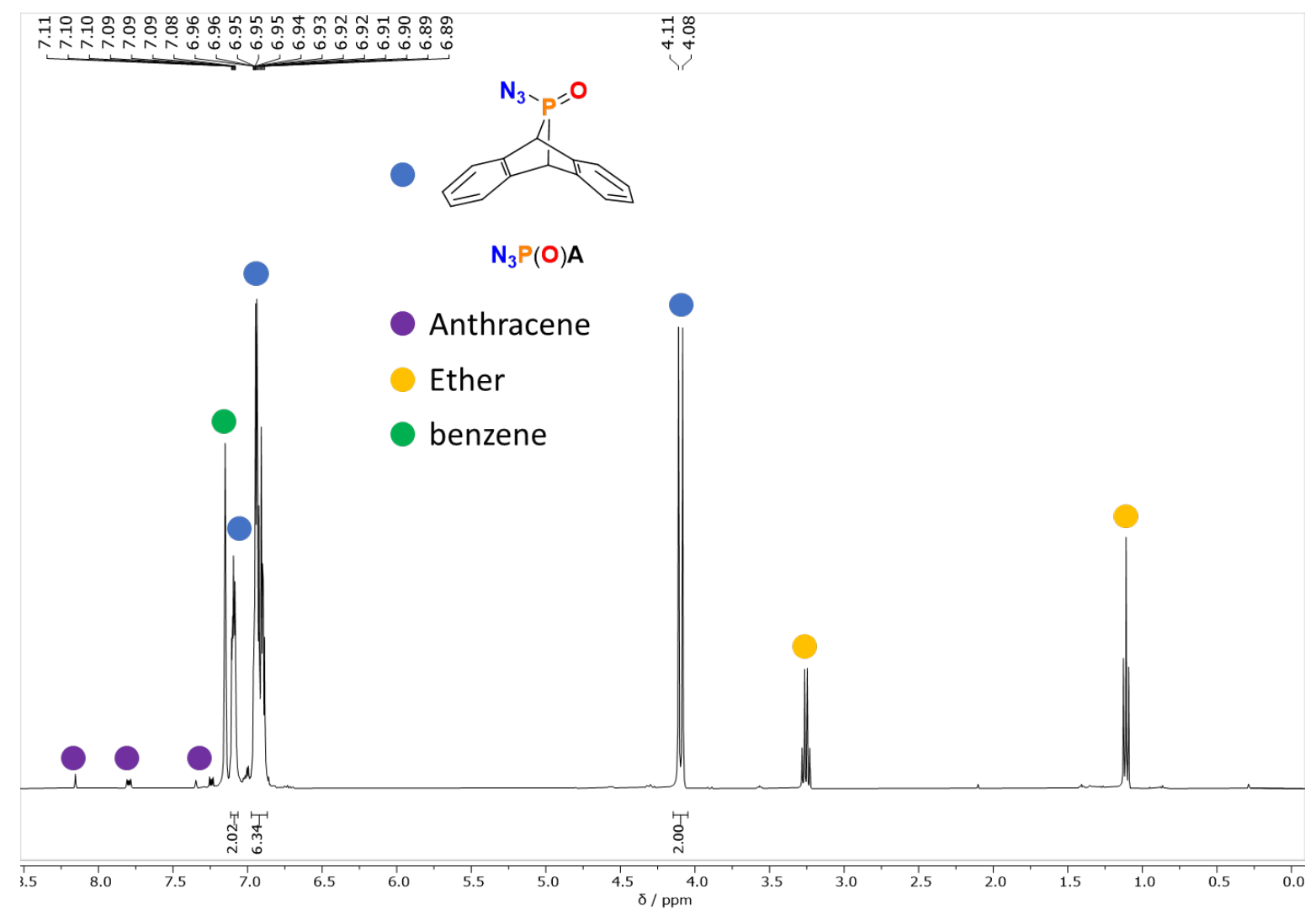

Figure S1: ${ }^{1} \mathrm{H}$ NMR (benzene- $d_{6}, 400 \mathrm{MHz}, 25^{\circ} \mathrm{C}$ ) spectrum of $\mathrm{N}_{3} \mathrm{P}(\mathrm{O}) \mathbf{A}$. 


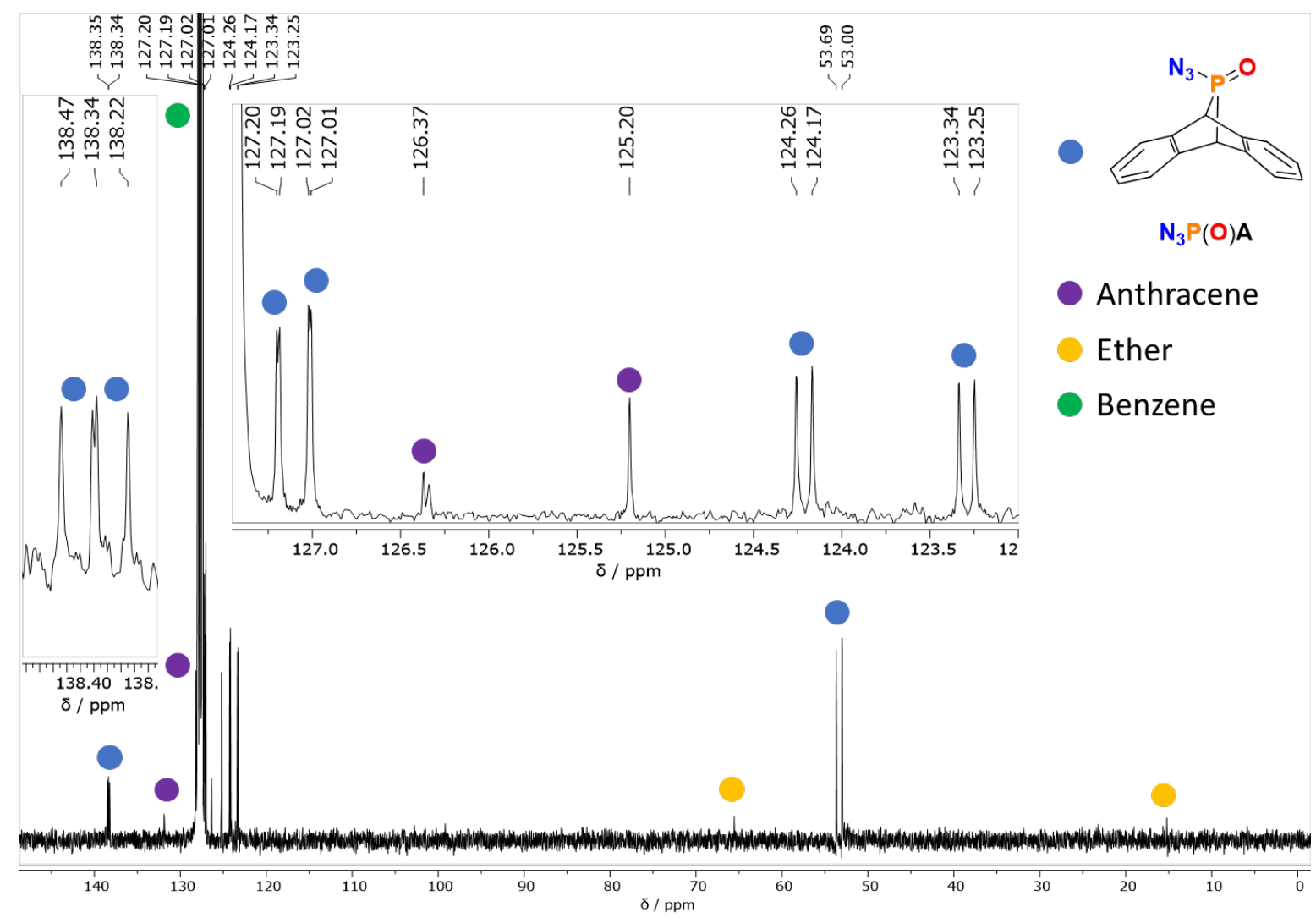

Figure S2: ${ }^{13} \mathrm{C}\left\{{ }^{1} \mathrm{H}\right\}$ NMR (benzene- $d_{6}, 101 \mathrm{MHz}, 25^{\circ} \mathrm{C}$ ) spectrum of $\mathrm{N}_{3} \mathrm{PA}$.

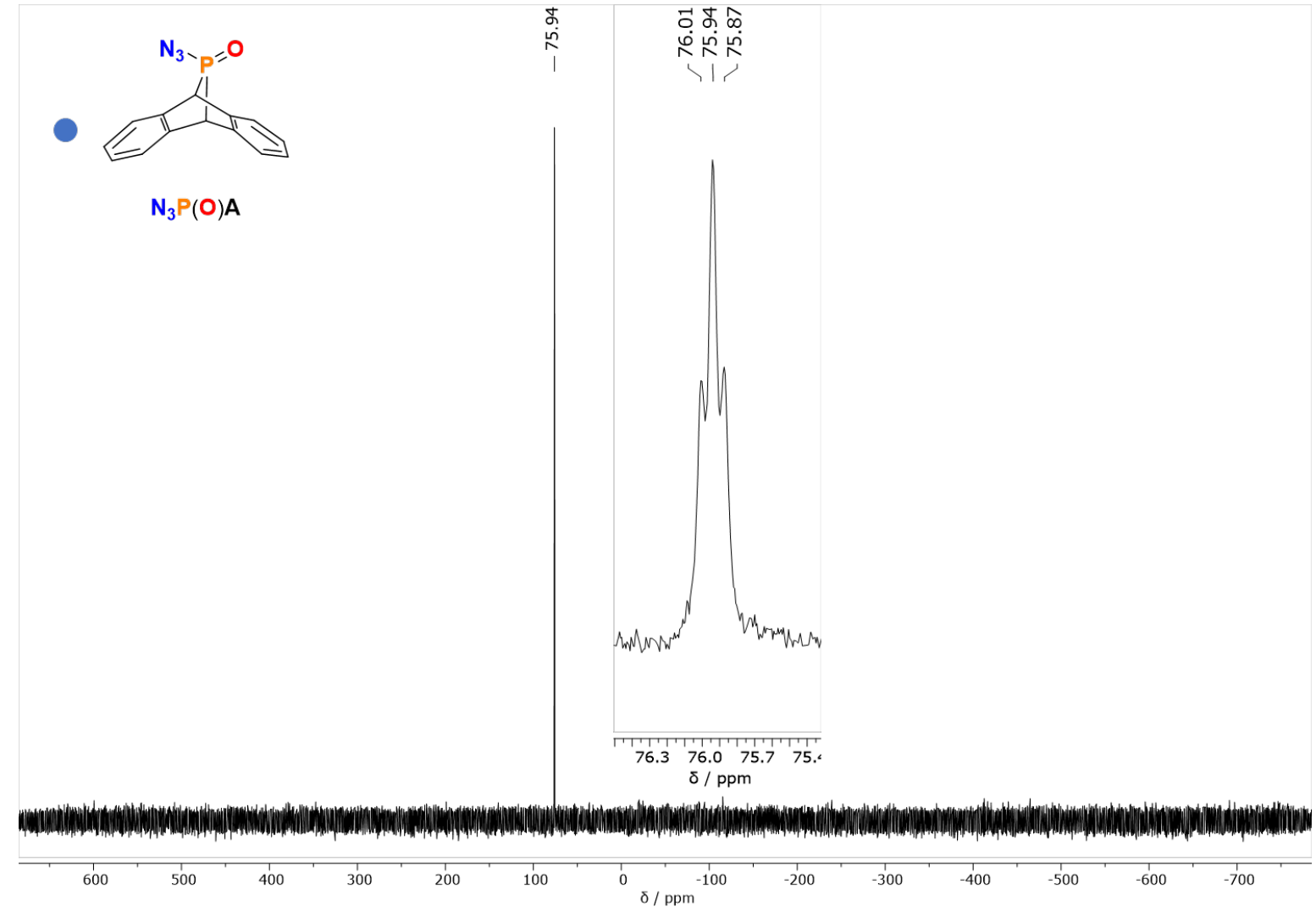

Figure S3: ${ }^{31} \mathrm{P}\left\{{ }^{1} \mathrm{H}\right\}$ and ${ }^{31} \mathrm{P}$ (inset) NMR (benzene- $d_{6}, 162 \mathrm{MHz}, 25^{\circ} \mathrm{C}$ ) spectrum of $\mathrm{N}_{3} \mathrm{P}(\mathrm{O}) \mathbf{A}$. 


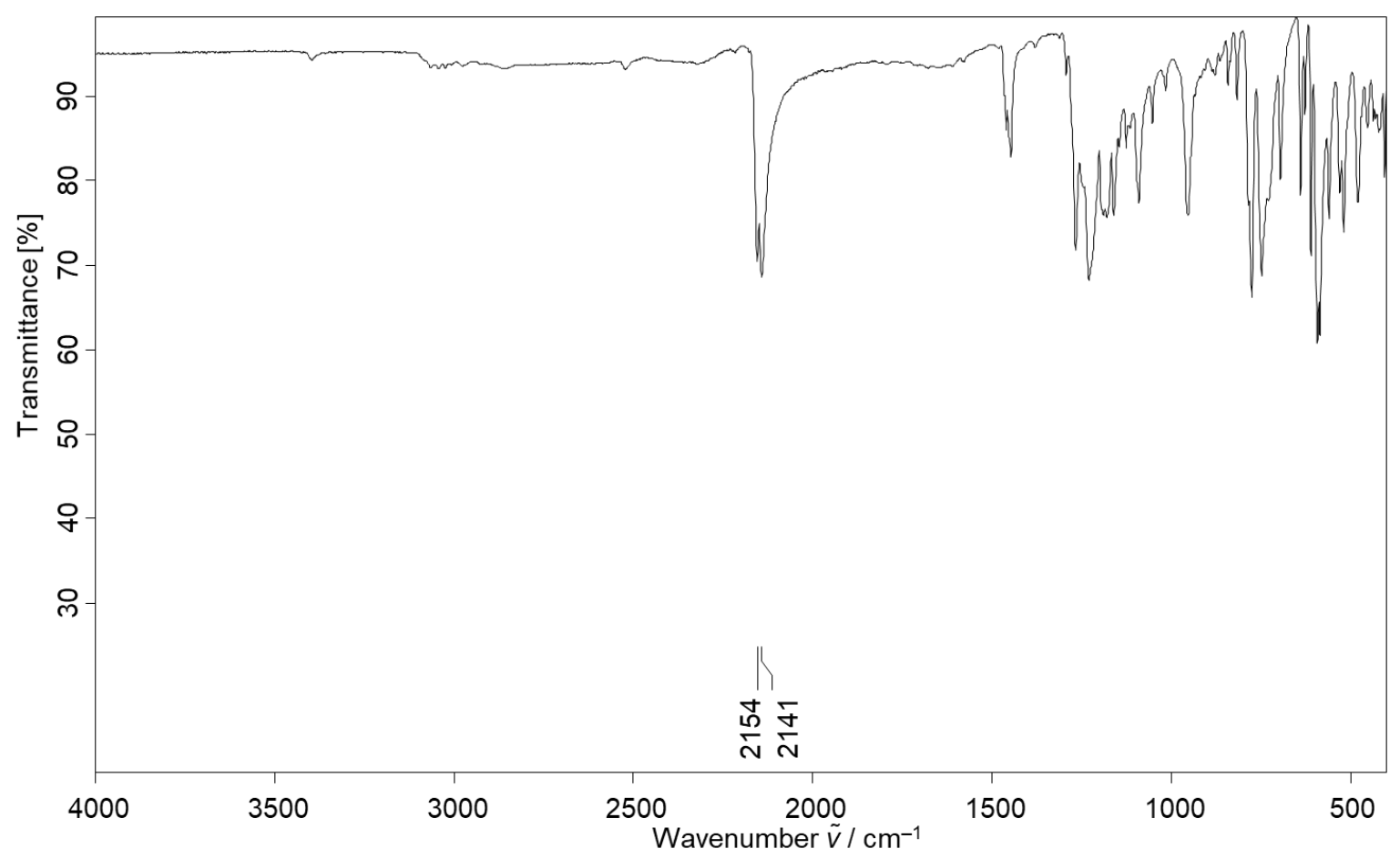

Figure S4: ATR-IR spectrum of solid $\mathrm{N}_{3} \mathrm{P}(\mathrm{O}) \mathrm{A}$.

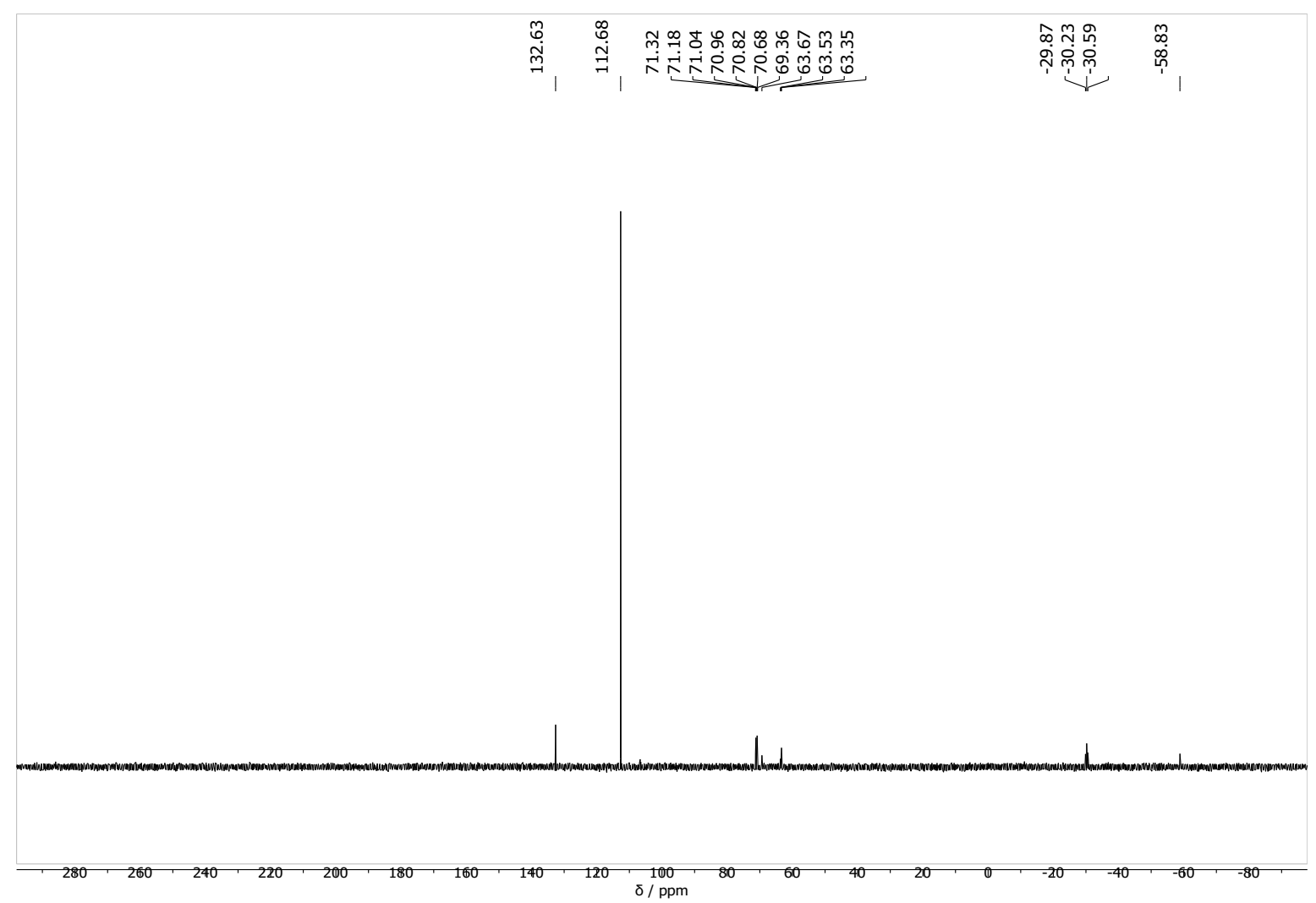

Figure S5: ${ }^{31} \mathrm{P}\left\{{ }^{1} \mathrm{H}\right\}$ NMR (benzene- $d_{6}, 162 \mathrm{MHz}, 25{ }^{\circ} \mathrm{C}$ ) spectrum of $\mathrm{N}_{3} \mathrm{P}(\mathrm{O}) \mathbf{A}$ after thermolysis for 60 minutes at $70{ }^{\circ} \mathrm{C}$. 


\section{Synthesis of $\mathrm{Cy}_{3} \mathrm{P}=\mathrm{NP}(\mathrm{O}) \mathrm{A}$}

Inside the glovebox, a $20 \mathrm{~mL}$ vial was charged with solid, colorless $\mathrm{N}_{3} \mathrm{P}(\mathrm{O}) \mathrm{A}(155 \mathrm{mg}, 0.58 \mathrm{mmol}, 1.0$ equiv), tricyclohexylphosphine ( $\mathrm{PCy}_{3}, 162 \mathrm{mg}, 0.78 \mathrm{mmol}, 1.0$ equiv) and $10 \mathrm{~mL}$ diethyl ether. The heterogeneous solution was stirred for $30 \mathrm{~min}$ at room temperature. Gas evolution occurred and a colorless precipitate formed that was filtered and washed with a minimal amount of pentane and further dried in the glovebox for $30 \mathrm{~min}$, giving up to $246 \mathrm{mg}$ (82\%) clean product. The identity of the product was confirmed by NMR as well as by an X-ray diffraction study performed on a crystal grown from diethyl ether at $-20{ }^{\circ} \mathrm{C}$ (Figure 4A). Crystals for elemental analysis were grown from a chloroform/pentane solution. One molecule of pentane and two molecules of chloroform are included in the elemental analysis result. Anal. Calcd for $\mathrm{C}_{39} \mathrm{H}_{57} \mathrm{Cl}_{6} \mathrm{NOP}_{2}$ : C, 56.40; H, 6.92; N, 1.69. Found: $\mathrm{C}$, 55.11; H, 6.91; N, 2.19. ${ }^{1} \mathrm{H}$ NMR (benzene- $\left.d_{6}, 400 \mathrm{MHz}, 25^{\circ} \mathrm{C}\right) \delta 7.41(\mathrm{~m}, 2 \mathrm{H}), 7.27(\mathrm{~m}, 2 \mathrm{H}), 7.08(\mathrm{~m}$, $2 \mathrm{H}), 7.01(\mathrm{~m}, 2 \mathrm{H}), 4.67\left(\mathrm{~d}, 2 \mathrm{H},{ }^{2} \mathrm{~J}_{\mathrm{PH}}=8.8 \mathrm{~Hz}\right), 1.63(\mathrm{~m}, 18 \mathrm{H}), 1.12(\mathrm{~m}, 15 \mathrm{H}) \mathrm{ppm} .{ }^{13} \mathrm{C}\left\{{ }^{1} \mathrm{H}\right\} \mathrm{NMR}$ (benzene- $\left.d_{6}, 101 \mathrm{MHz}, 25^{\circ} \mathrm{C}\right) \delta 144.7(\mathrm{~d}, J=8.7 \mathrm{~Hz}), 142.9(\mathrm{~d}, J=10.0 \mathrm{~Hz}), 125.6,124.9,123.8(\mathrm{~d}, J$ $=8.4 \mathrm{~Hz}), 122.9(\mathrm{~d}, J=7.9 \mathrm{~Hz}), 57.9(\mathrm{dd}, J=76.3,3.0 \mathrm{~Hz}), 35.5$ (d, $J=1.9 \mathrm{~Hz}), 34.9$ (d, $J=1.9 \mathrm{~Hz})$, 27.1, 27.0 26.7, 26.6, $26.3 \mathrm{ppm} .{ }^{31} \mathrm{P}\left\{{ }^{1} \mathrm{H}\right\}$ NMR (benzene- $\left.d_{6}, 162 \mathrm{MHz}, 25{ }^{\circ} \mathrm{C}\right) \delta 82.9(\mathrm{~d}, J=21.4 \mathrm{~Hz}$ ), $32.3(\mathrm{~d}, J=21.4 \mathrm{~Hz}) \mathrm{ppm}$.

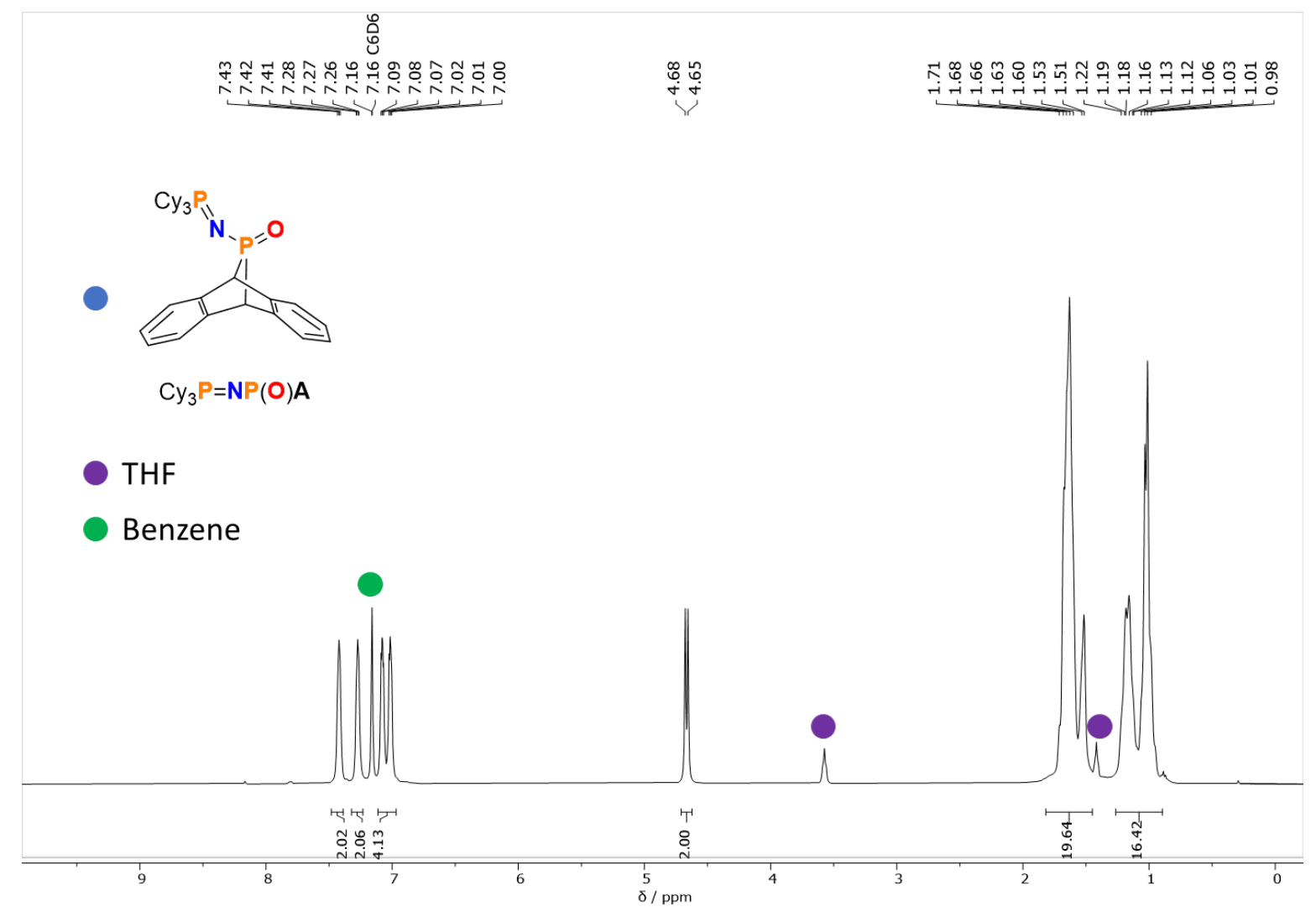

Figure S6: ${ }^{1} \mathrm{H}$ NMR (benzene- $d_{6}, 400 \mathrm{MHz}, 25{ }^{\circ} \mathrm{C}$ ) spectrum of $\mathrm{Cy}_{3} \mathrm{P}=\mathrm{NP}(\mathrm{O}) \mathbf{A}$. 

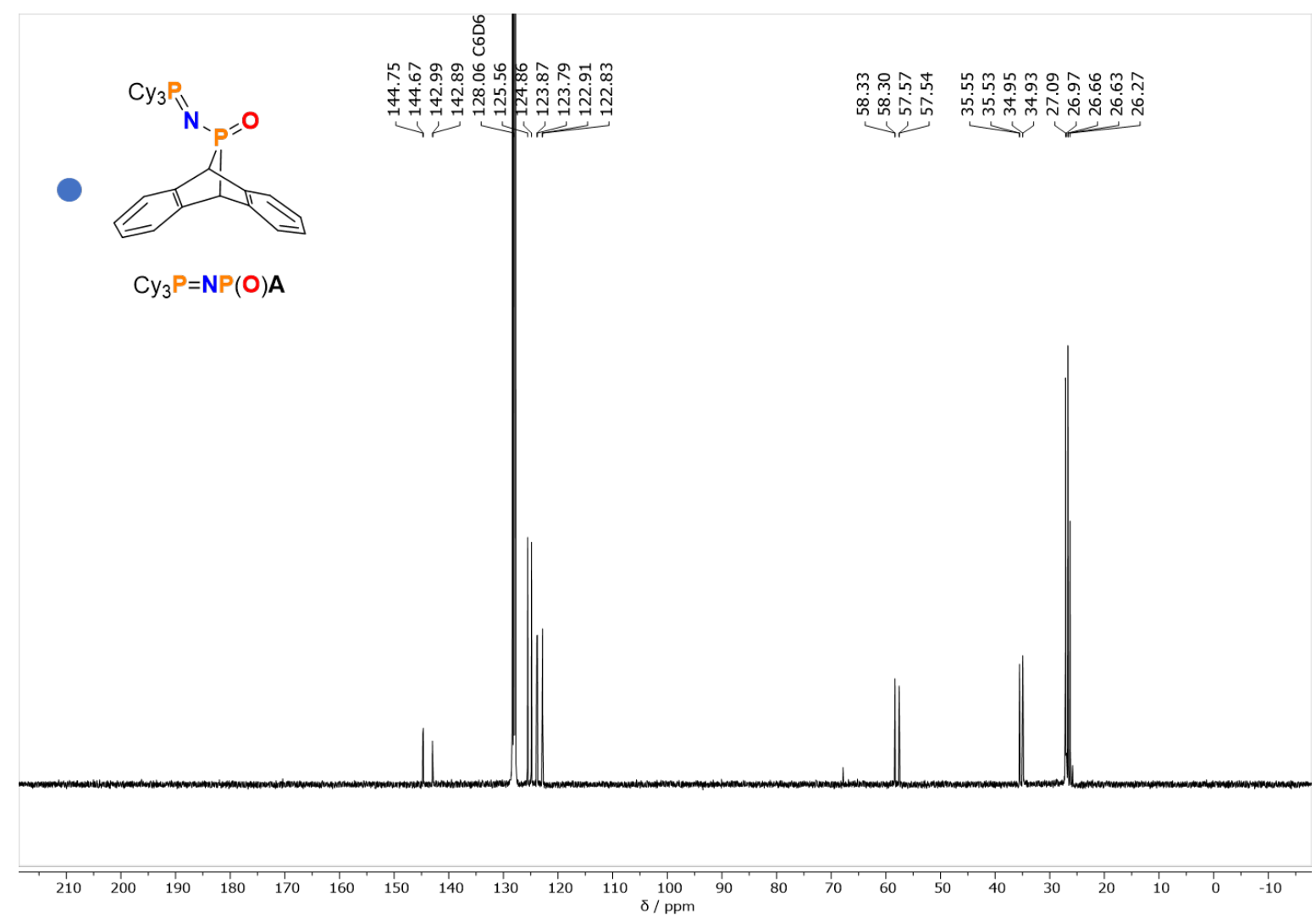

Figure S7: ${ }^{13} \mathrm{C}\left\{{ }^{1} \mathrm{H}\right\}$ NMR (benzene- $d_{6}, 101 \mathrm{MHz}, 25^{\circ} \mathrm{C}$ ) spectrum of $\mathrm{Cy}_{3} \mathrm{P}=\mathrm{NP}(\mathrm{O}) \mathbf{A}$.
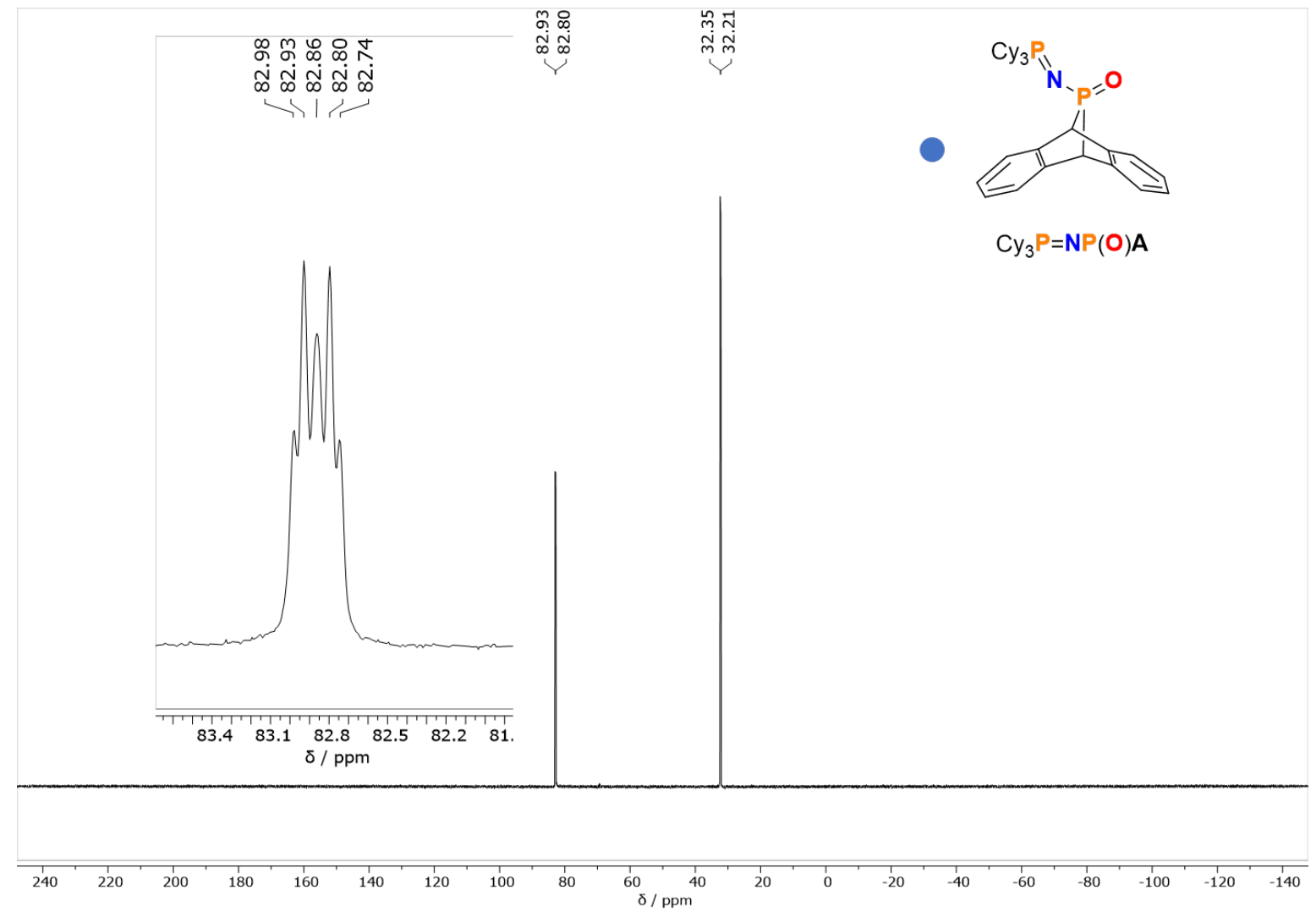

Figure S8: ${ }^{31} \mathrm{P}\left\{{ }^{1} \mathrm{H}\right\}$ and ${ }^{31} \mathrm{P}$ (inset) NMR (benzene- $d_{6}, 162 \mathrm{MHz}, 25^{\circ} \mathrm{C}$ ) spectrum of $\mathrm{Cy} y_{3} \mathrm{P}=\mathrm{NP}(\mathrm{O}) \mathbf{A}$. 


\section{Synthesis of $\mathrm{Cy}_{3} \mathrm{P}-\mathrm{NP}(\mathrm{A}) \mathrm{O}-\mathrm{B}\left(\mathrm{C}_{6} \mathrm{~F}_{5}\right)_{3}$}

Inside the glovebox, a $20 \mathrm{~mL}$ vial was charged with solid, colorless $\mathrm{Cy}_{3} \mathrm{PNP}(\mathrm{O}) \mathrm{A}$ (50.8 mg, $0.098 \mathrm{mmol}$, 1.0 equiv), tris(pentafluorophenyl)borane $\left(\mathrm{B}_{(}\left(\mathrm{C}_{6} \mathrm{~F}_{5}\right)_{3}, 50.0 \mathrm{mg}, 0.098 \mathrm{mmol}, 1.0\right.$ equiv) and $5 \mathrm{~mL}$ dichloromethane. The solution was stirred for $10 \mathrm{~min}$ at room temperature and all volatile materials were removed under reduced pressure, yielding $\mathrm{Cy}_{3} \mathrm{P}-\mathrm{NP}(\mathrm{A}) \mathrm{O}-\mathrm{B}\left(\mathrm{C}_{6} \mathrm{~F}_{5}\right)_{3}$ quantitatively. The identity of the product was confirmed by NMR as well as by an X-ray diffraction study performed on a crystal grown from diethyl ether at $-20{ }^{\circ} \mathrm{C}$ (Figure 4B). Crystals for elemental analysis were grown from a chloroform/pentane solution. One molecule of pentane and two molecules of chloroform are included in the elemental analysis. Anal. Calcd for $\mathrm{C}_{57} \mathrm{H}_{57} \mathrm{BCl}_{6} \mathrm{~F}_{15} \mathrm{NOP}_{2}$ : $\mathrm{C}, 51.00 ; \mathrm{H}, 4.28 ; \mathrm{N}, 1.04$. Found: $\mathrm{C}$, 50.66; H, 4.02; N, 1.34. ${ }^{1} \mathrm{H}$ NMR (chloroform- $\left.d, 500 \mathrm{MHz}, 25^{\circ} \mathrm{C}\right) \delta 7.36(\mathrm{~m}, 2 \mathrm{H}), 7.17$ (m, 4H), 6.93 (m, 2H), $4.68\left(\mathrm{~d}, 2 \mathrm{H},{ }^{2} J_{\mathrm{PH}}=12.2 \mathrm{~Hz}\right), 1.73(\mathrm{~m}, 9 \mathrm{H}), 1.47(\mathrm{~m}, 6 \mathrm{H}), 1.27(\mathrm{~m}, 3 \mathrm{H}), 1.04(\mathrm{~m}, 15 \mathrm{H}) \mathrm{ppm}$. ${ }^{13} \mathrm{C}\left\{{ }^{1} \mathrm{H}\right\}$ NMR (chloroform- $d, 126 \mathrm{MHz}, 25{ }^{\circ} \mathrm{C}$ ) $\delta 148.8$ (b), 146.9 (b), 141.3 (d, $J=15.3 \mathrm{~Hz}$ ), 140.3 (b), 140.1 (d, $J=11.2 \mathrm{~Hz}), 138.3$ (b), 137.7 (b), 135.7 (b), 126.5, 126.0, 124.4 (d, $J=10.4 \mathrm{~Hz}$ ), 123.5 (d, $J$ $=9.2 \mathrm{~Hz}), 54.8(\mathrm{~d}, J=89.1 \mathrm{~Hz}), 35.8,35.3,26.6,26.526 .3,26.2,25.8 \mathrm{ppm} .{ }^{31} \mathrm{P}\left\{{ }^{1} \mathrm{H}\right\}$ NMR (chloroform$\left.d, 203 \mathrm{MHz}, 25{ }^{\circ} \mathrm{C}\right) \delta 82.5(\mathrm{~d}, J=16.7 \mathrm{~Hz}), 32.9(\mathrm{~d}, J=16.9 \mathrm{~Hz}) \mathrm{ppm} .{ }^{19} \mathrm{~F}$ NMR (chloroform- $d, 471$ $\left.\mathrm{MHz}, 25^{\circ} \mathrm{C}\right) \delta-133.4(\mathrm{~m}),-160.4(\mathrm{t}, J=20.5 \mathrm{~Hz}),-165.5(\mathrm{~m}) \mathrm{ppm} .{ }^{11} \mathrm{~B}$ NMR (chloroform- $d, 161 \mathrm{MHz}$, $\left.25^{\circ} \mathrm{C}\right) \delta-3.88\left(\mathrm{~b}, v_{1 / 2}=341 \mathrm{~Hz}\right) \mathrm{ppm}$.

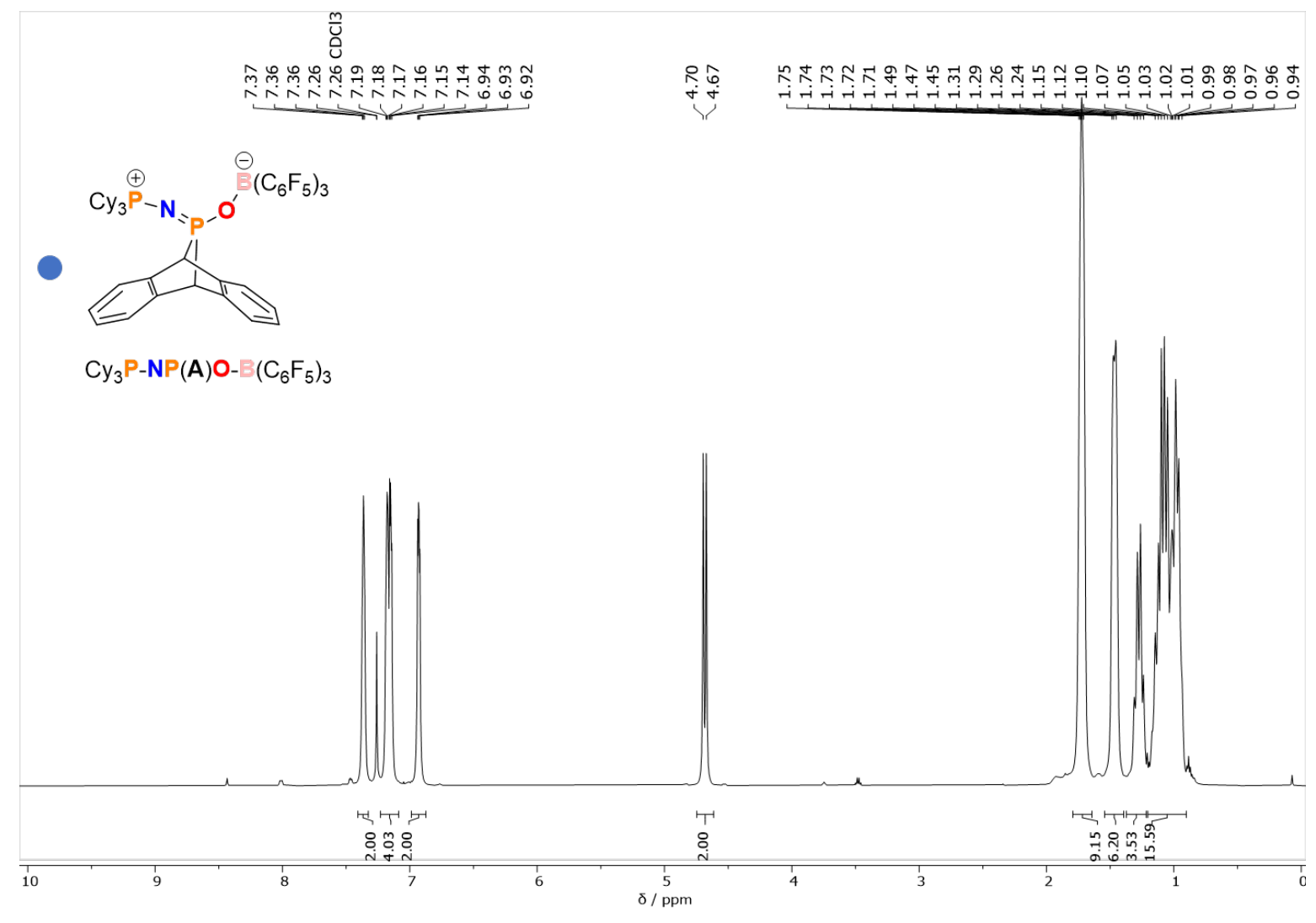

Figure S9: ${ }^{1} \mathrm{H}$ NMR (chloroform- $d, 500 \mathrm{MHz}, 25{ }^{\circ} \mathrm{C}$ ) spectrum of $\mathrm{Cy}_{3} \mathrm{P}-\mathrm{NP}(\mathrm{A}) \mathrm{O}-\mathrm{B}\left(\mathrm{C}_{6} \mathrm{~F}_{5}\right)_{3}$. 


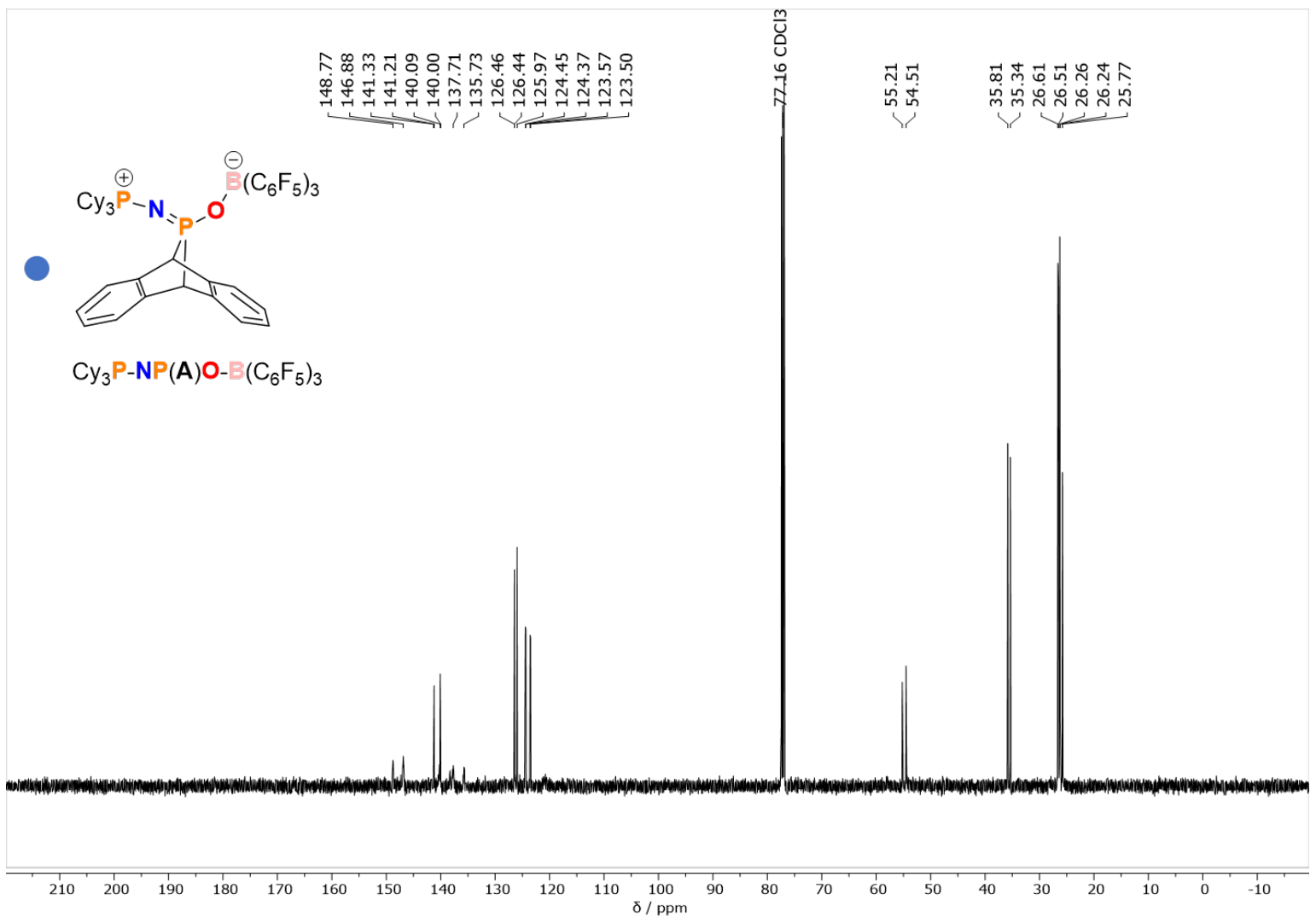

Figure S10: ${ }^{13} \mathrm{C}\left\{{ }^{1} \mathrm{H}\right\}$ NMR (chloroform- $d, 126 \mathrm{MHz}, 25^{\circ} \mathrm{C}$ ) spectrum of $\mathrm{Cy}_{3} \mathrm{P}-\mathrm{NP}(\mathrm{A}) \mathrm{O}-\mathrm{B}\left(\mathrm{C}_{6} \mathrm{~F}_{5}\right)_{3}$.
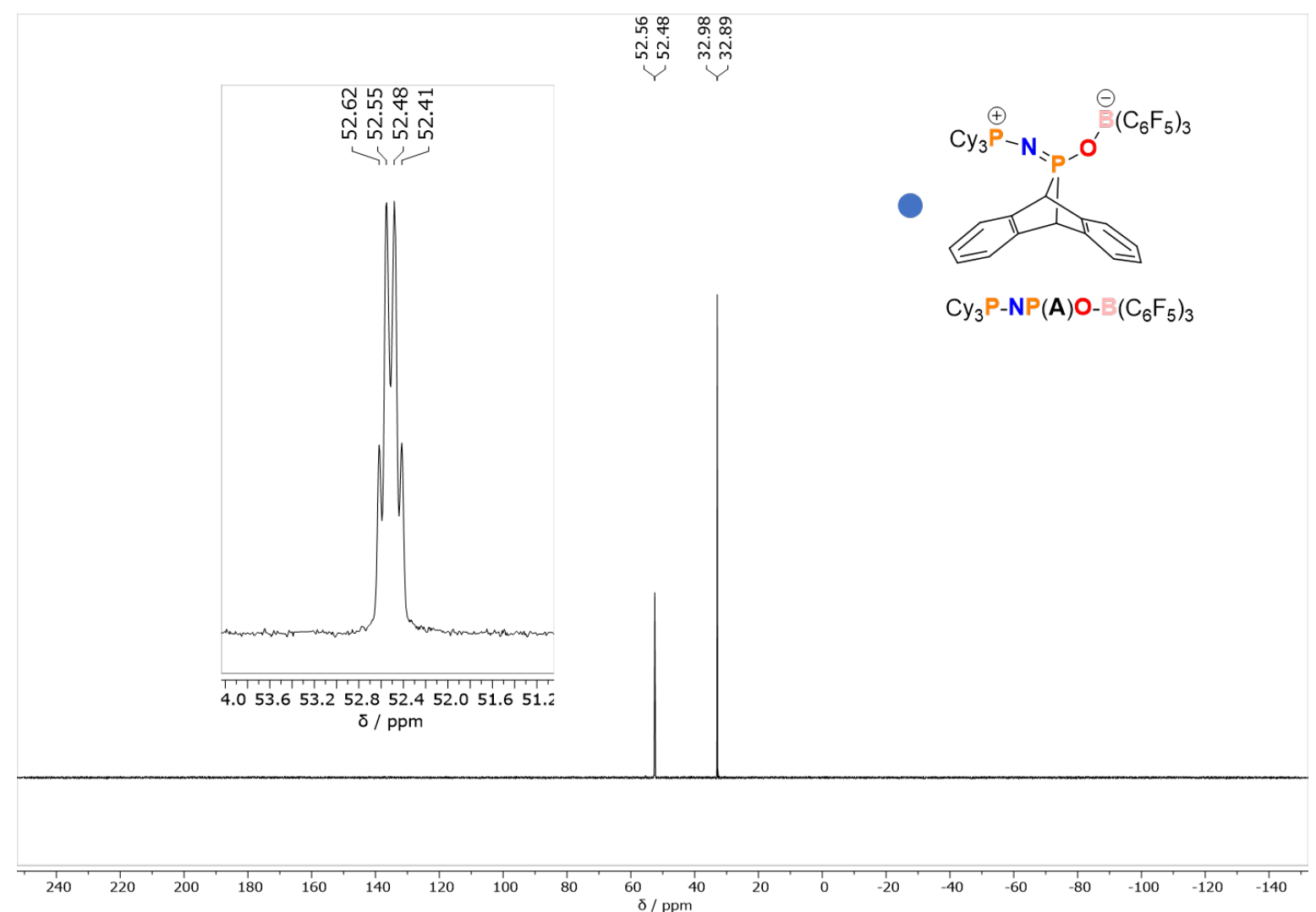

Figure S11: ${ }^{31} \mathrm{P}\left\{{ }^{1} \mathrm{H}\right\}$ and ${ }^{31} \mathrm{P}$ (inset) NMR (chloroform- $d, 203 \mathrm{MHz}, 25^{\circ} \mathrm{C}$ ) spectrum of $\mathrm{Cy}_{3} \mathrm{P}-\mathrm{NP}(\mathrm{A}) \mathrm{O}-\mathrm{B}\left(\mathrm{C}_{6} \mathrm{~F}_{5}\right)_{3}$. 


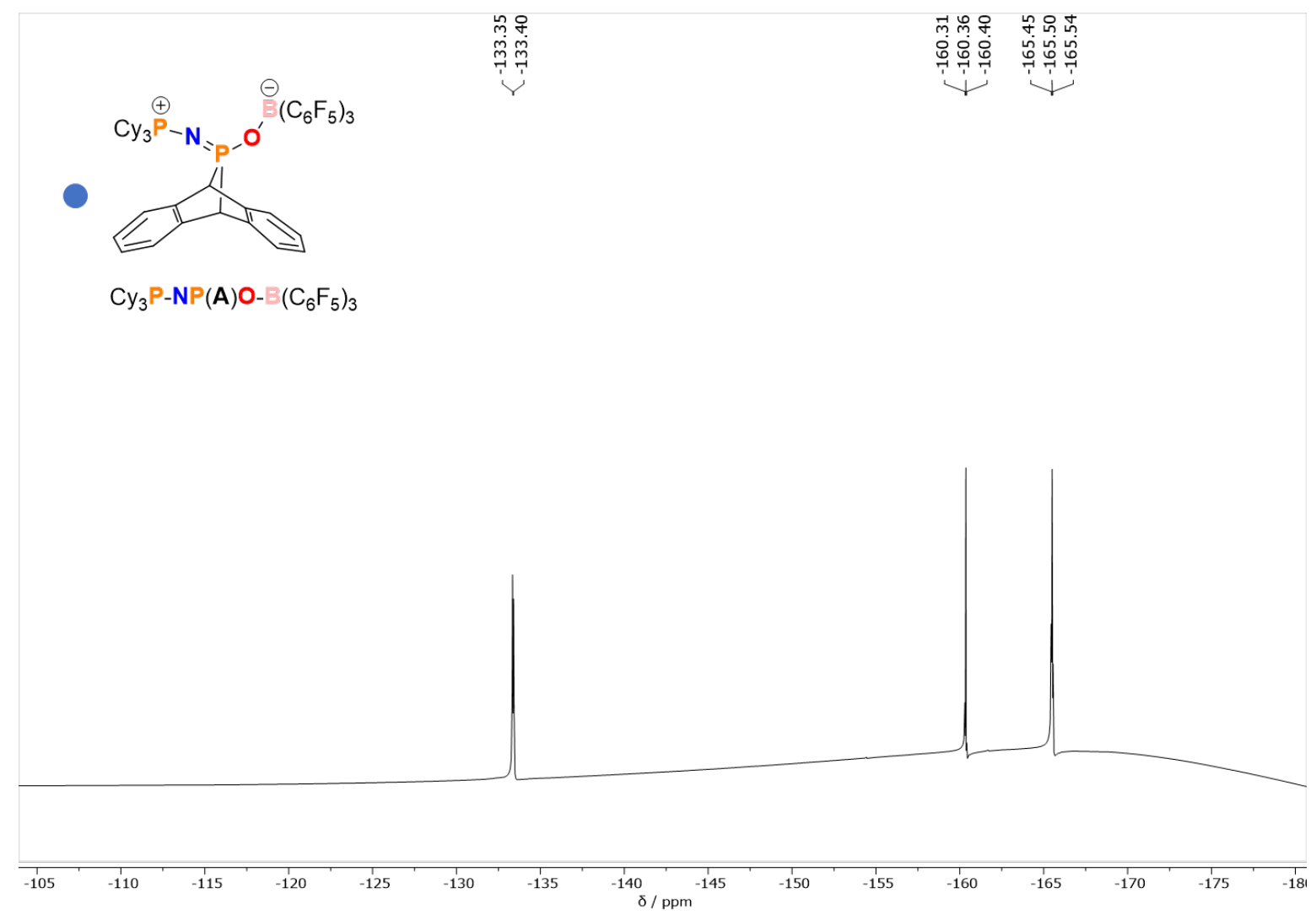

Figure S12: ${ }^{19} \mathrm{~F}$ NMR (chloroform- $d, 471 \mathrm{MHz}, 25^{\circ} \mathrm{C}$ ) spectrum of $\mathrm{Cy}_{3} \mathrm{P}-\mathrm{NP}(\mathbf{A}) \mathrm{O}-\mathrm{B}\left(\mathrm{C}_{6} \mathrm{~F}_{5}\right)_{3}$.

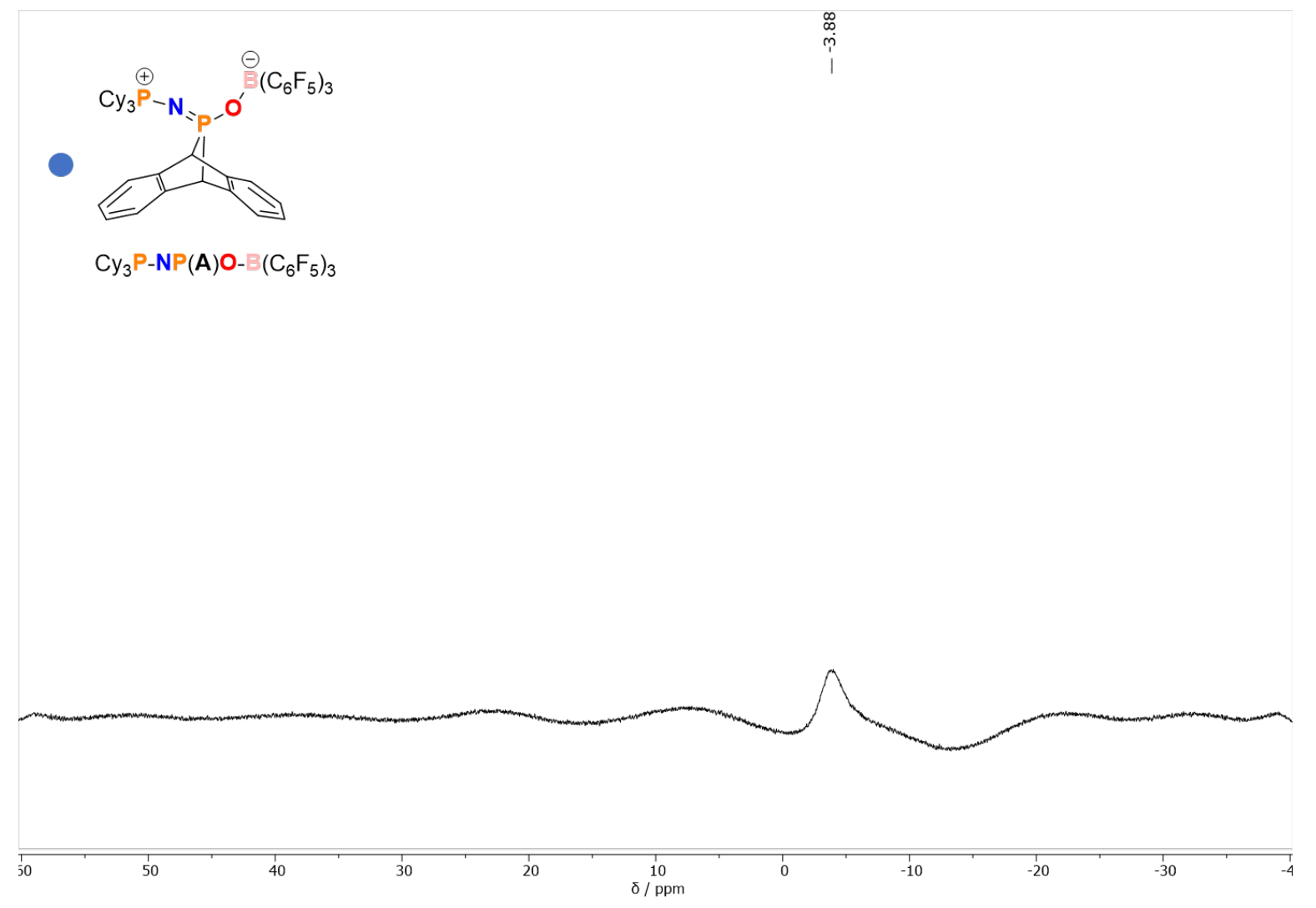

Figure S13: ${ }^{11} \mathrm{~B}$ NMR (chloroform- $d, 161 \mathrm{MHz}, 25{ }^{\circ} \mathrm{C}$ ) spectrum of $\mathrm{Cy}_{3} \mathrm{P}-\mathrm{NP}(\mathbf{A}) \mathrm{O}-\mathrm{B}\left(\mathrm{C}_{6} \mathrm{~F}_{5}\right)_{3}$. 


\section{Synthesis of $\mathrm{Cy}_{3} \mathrm{P}-\mathrm{NPO}-\mathrm{B}\left(\mathrm{C}_{6} \mathrm{~F}_{5}\right)_{3}$}

Inside the glovebox, a quartz NMR tube with a J young valve was charged with solid, colorless $\mathrm{Cy}_{3} \mathrm{P}-$ $\mathrm{NP}(\mathrm{A}) \mathrm{O}-\mathrm{B}\left(\mathrm{C}_{6} \mathrm{~F}_{5}\right)_{3}(100 \mathrm{mg}, 0.192 \mathrm{mmol})$ and $5 \mathrm{~mL}$ benzene or toluene. The homogenous solution was irradiated for $220 \mathrm{~min}$ with $254 \mathrm{~nm}$ light in a photoreactor outside the glovebox and the reaction followed by NMR spectroscopy. The tube was brought back inside the glovebox and the colorless precipitate that was formed during the irradiation filtered off. The filtrate was layered with pentane and placed in in the freezer $\left(-20^{\circ} \mathrm{C}\right)$ over night, yielding $35.3 \mathrm{mg}$ crystalline $\mathrm{Cy}_{3} \mathrm{P}-\mathrm{NPO}-\mathrm{B}\left(\mathrm{C}_{6} \mathrm{~F}_{5}\right)_{3}$ in $42 \%$ yield. The identity of the product was confirmed by NMR as well as by an X-ray diffraction study performed on a crystal directly grown from an irradiated benzene/pentane solution at $-20{ }^{\circ} \mathrm{C}$ (Figure $4 \mathrm{C}$ ). The compound did not pass elemental analysis probably due to the poor thermal stability of the molecule. ${ }^{1} \mathrm{H}$ NMR (chloroform- $\left.d, 500 \mathrm{MHz}, 25{ }^{\circ} \mathrm{C}\right) \delta 2.16(\mathrm{~m}, 2 \mathrm{H}), 1.80(\mathrm{~m}, 15 \mathrm{H}), 1.28(\mathrm{~m}, 16 \mathrm{H}) \mathrm{ppm} .{ }^{13} \mathrm{C}\left\{{ }^{1} \mathrm{H}\right\} \mathrm{NMR}$ (chloroform- $d, 126 \mathrm{MHz}, 25^{\circ} \mathrm{C}$ ) $\delta 148.9$ (b), 147.0 (b), 140.7 (b), 138.7 (b), 138.0 (b), 136.1 (b), 34.2 (d, $J=2.4 \mathrm{~Hz}$ ), 33.8 (d, $J=2.4 \mathrm{~Hz}), 26.6,26.5,26.4,26.3,25.6$ ppm. ${ }^{31} \mathrm{P}\left\{{ }^{1} \mathrm{H}\right\}$ NMR (chloroform- $d, 203$ $\left.\mathrm{MHz}, 25^{\circ} \mathrm{C}\right) \delta 271.1(\mathrm{dp}, J=77.4,25.5 \mathrm{~Hz}), 44.1(\mathrm{~d}, J=78.2 \mathrm{~Hz}) \mathrm{ppm} .{ }^{19} \mathrm{~F}$ NMR (chloroform- $d, 471$ $\left.\mathrm{MHz}, 25^{\circ} \mathrm{C}\right) \delta-133.4(\mathrm{td}, J=24.8,8.5 \mathrm{~Hz}),-158.9(\mathrm{t}, J=20.3 \mathrm{~Hz}), 164.78(\mathrm{td}, J=22.9,8.4 \mathrm{~Hz}) \mathrm{ppm}$. ${ }^{11} \mathrm{~B}$ NMR (chloroform- $\left.d, 161 \mathrm{MHz}, 25{ }^{\circ} \mathrm{C}\right) \delta-3.06\left(\mathrm{~b}, v_{1 / 2}=381 \mathrm{~Hz}\right) \mathrm{ppm}$.

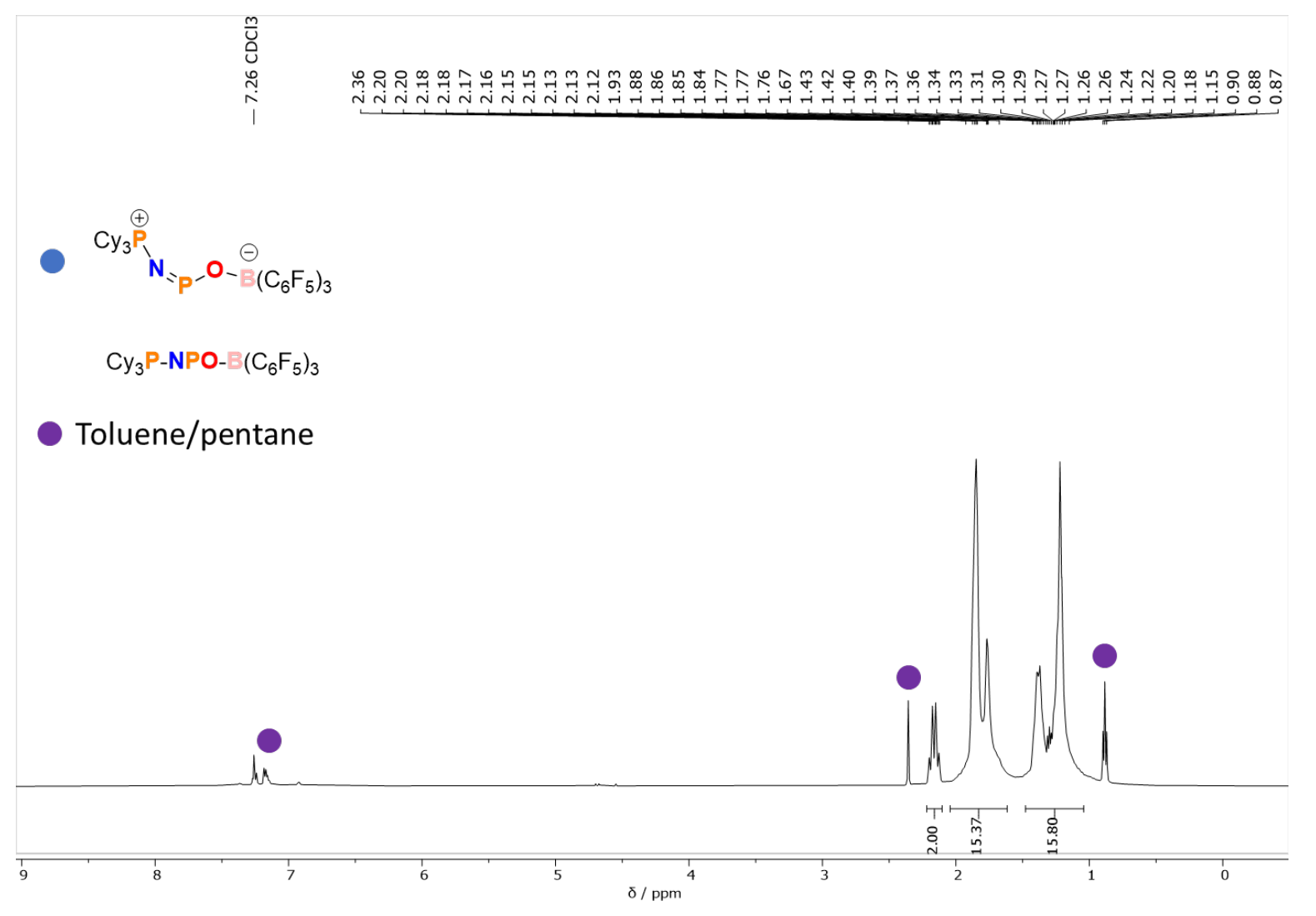

Figure S14: ${ }^{1} \mathrm{H}$ NMR (chloroform- $d, 500 \mathrm{MHz}, 25^{\circ} \mathrm{C}$ ) spectrum of $\mathrm{Cy}_{3} \mathrm{P}-\mathrm{NPO}-\mathrm{B}\left(\mathrm{C}_{6} \mathrm{~F}_{5}\right)_{3}$. 

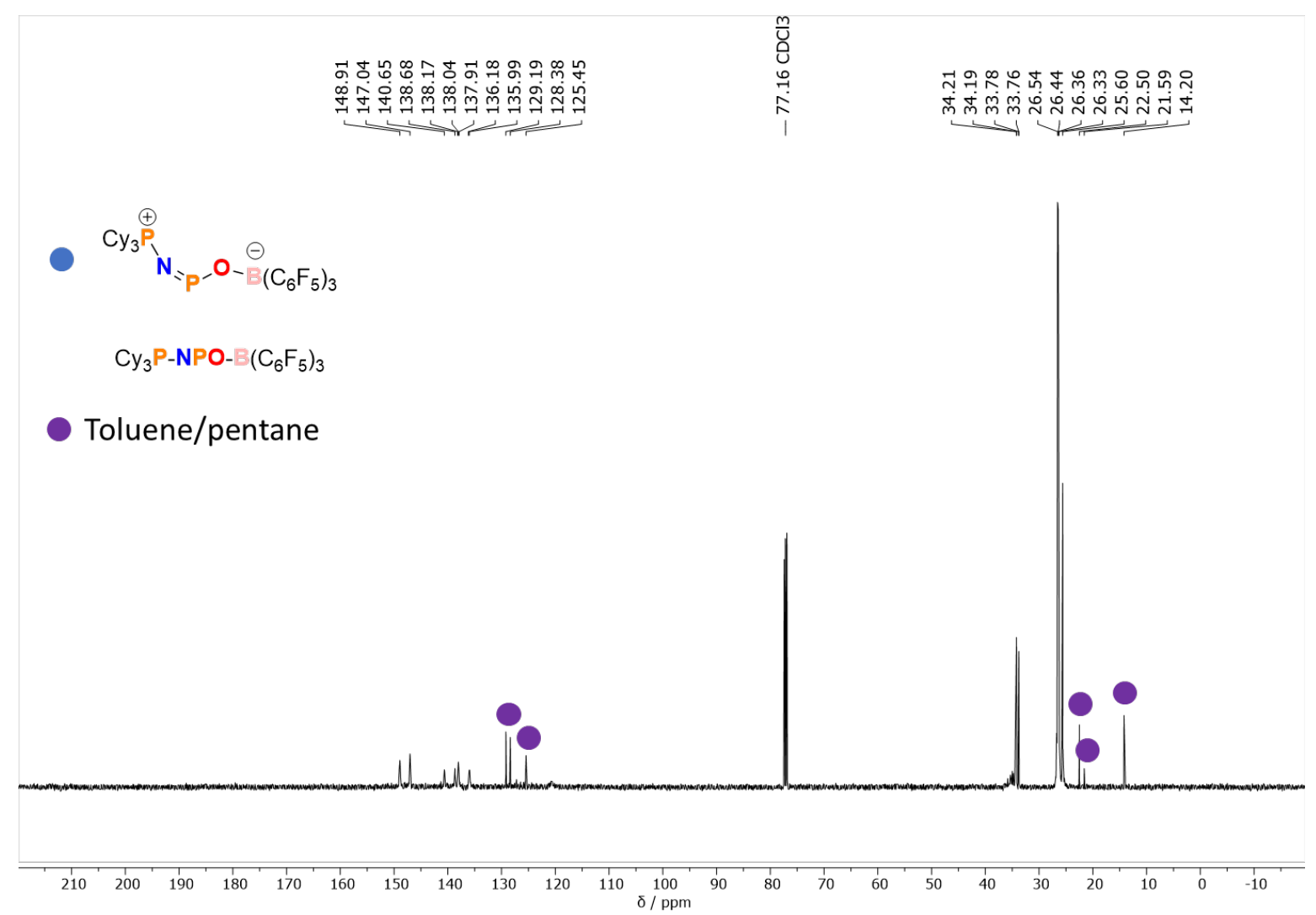

Figure S15: ${ }^{13} \mathrm{C}\left\{{ }^{1} \mathrm{H}\right\}$ NMR (chloroform- $d, 126 \mathrm{MHz}, 25^{\circ} \mathrm{C}$ ) spectrum of $\mathrm{Cy}_{3} \mathrm{P}-\mathrm{NPO}-\mathrm{B}\left(\mathrm{C}_{6} \mathrm{~F}_{5}\right)_{3}$.

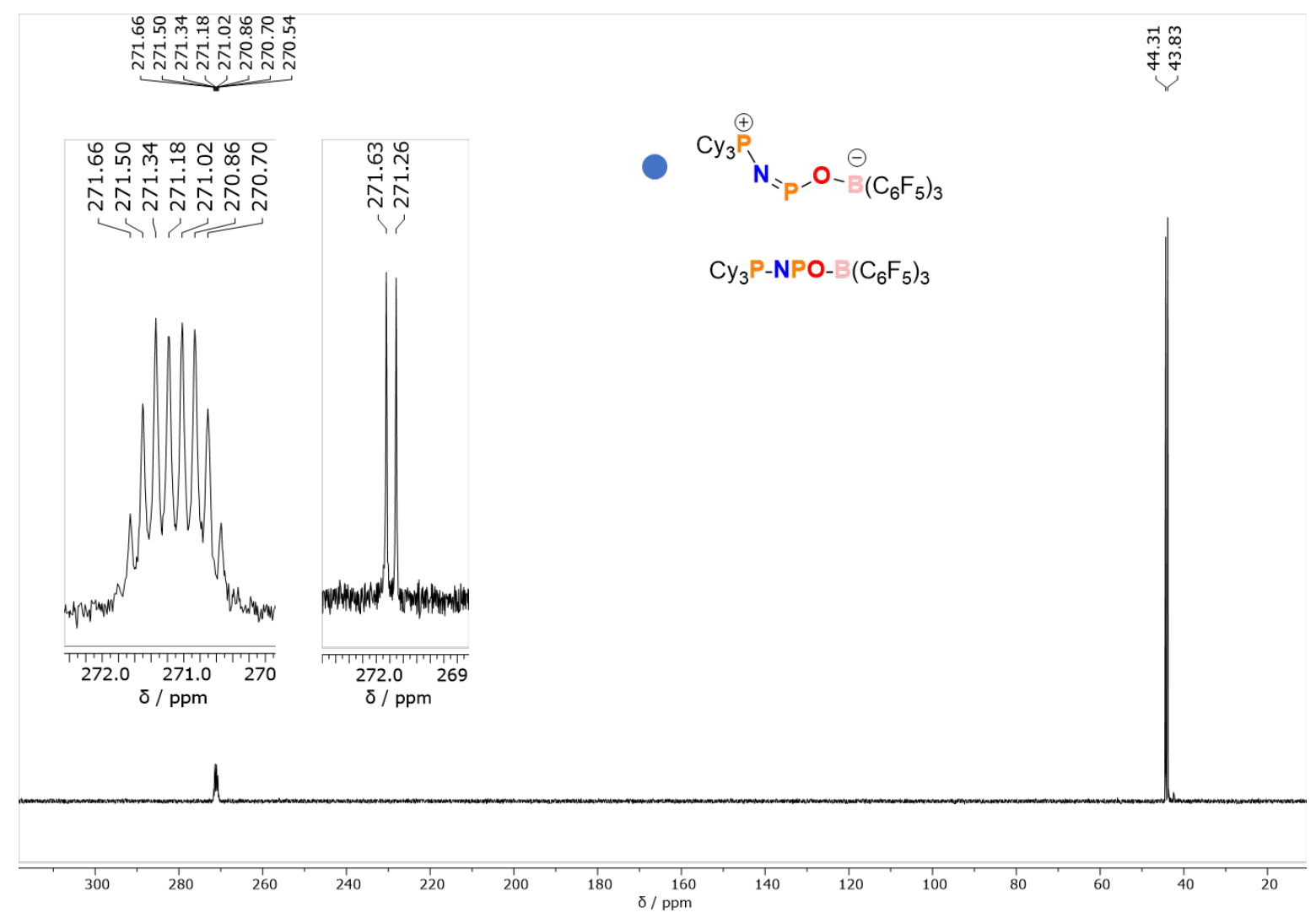

Figure S16: ${ }^{31} \mathrm{P}\left\{{ }^{1} \mathrm{H}\right\}$ and enlarged ${ }^{31} \mathrm{P}\left\{{ }^{1} \mathrm{H}\right\}$ (inset left) as well as ${ }^{31} \mathrm{P}\left\{{ }^{1} \mathrm{H},{ }^{19} \mathrm{~F}\right\}$ (inset right) NMR (chloroform- $d$, $\left.203 \mathrm{MHz}, 25{ }^{\circ} \mathrm{C}\right)$ spectrum of $\mathrm{Cy}_{3} \mathrm{P}-\mathrm{NPO}-\mathrm{B}\left(\mathrm{C}_{6} \mathrm{~F}_{5}\right)_{3}$. 


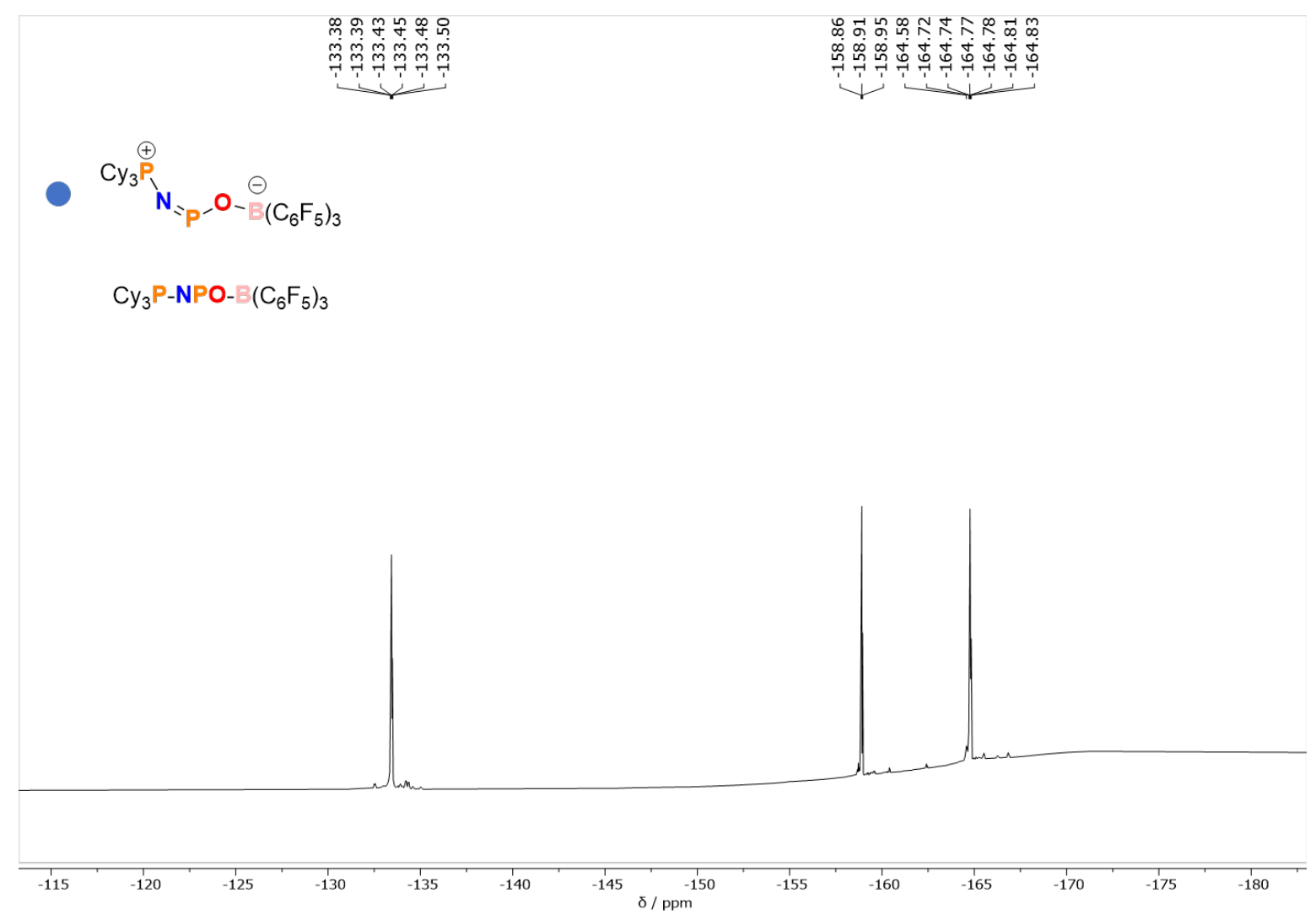

Figure S17: ${ }^{19} \mathrm{~F}$ NMR (chloroform- $d, 471 \mathrm{MHz}, 25{ }^{\circ} \mathrm{C}$ ) spectrum of $\mathrm{Cy}_{3} \mathrm{P}-\mathrm{NPO}-\mathrm{B}\left(\mathrm{C}_{6} \mathrm{~F}_{5}\right)_{3}$.

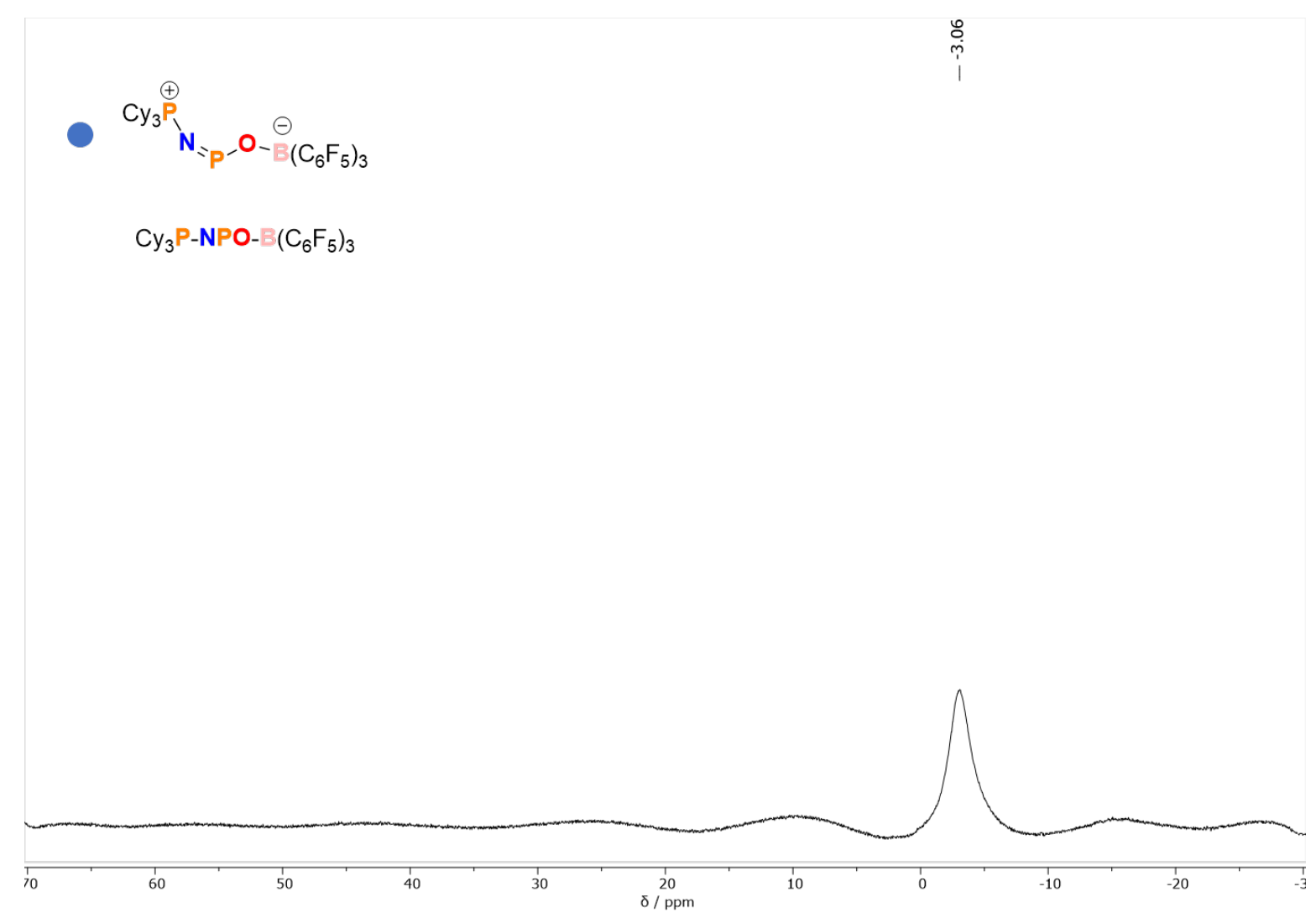

Figure S18: ${ }^{11} \mathrm{~B}$ NMR (chloroform- $d, 161 \mathrm{MHz}, 25{ }^{\circ} \mathrm{C}$ ) spectrum of $\mathrm{Cy}_{3} \mathrm{P}-\mathrm{NPO}-\mathrm{B}\left(\mathrm{C}_{6} \mathrm{~F}_{5}\right)_{3}$. 


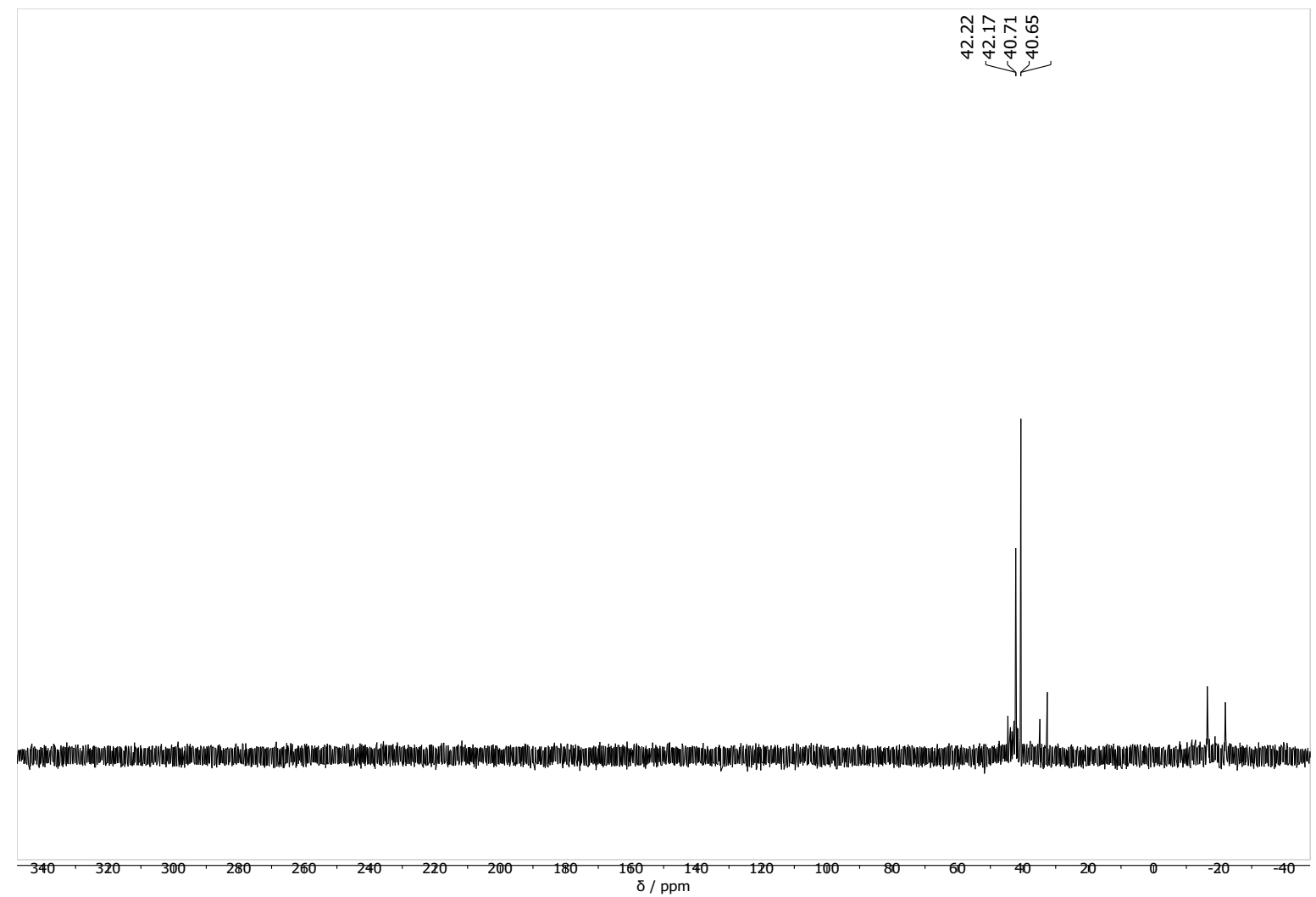

Figure S19: ${ }^{31} \mathrm{P}\left\{{ }^{1} \mathrm{H}\right\}$ NMR (benzene- $d_{6}, 203 \mathrm{MHz}, 25^{\circ} \mathrm{C}$ ) spectrum after thermolysis of $\mathrm{Cy}_{3} \mathrm{P}-\mathrm{NPO}-\mathrm{B}\left(\mathrm{C}_{6} \mathrm{~F}_{5}\right)_{3}$ at $80{ }^{\circ} \mathrm{C}$ for $3 \mathrm{~h}$. 


\section{Monitoring the Decay of $\mathrm{N}_{3} \mathrm{P}(\mathrm{O}) \mathrm{A}$ by ${ }^{1} \mathrm{H}$ NMR Spectroscopy}

In solution $\mathrm{N}_{3} \mathrm{P}(\mathrm{O}) \mathrm{A}$ decomposes upon either thermal or photochemical activation. After $1 \mathrm{~h}$ irradiation of a quartz NMR tube containing a solution of $\mathrm{N}_{3} \mathrm{P}(\mathrm{O}) \mathbf{A}$ in benzene- $d_{6}$ at $\lambda=254 \mathrm{~nm}$ only resonances of $\mathbf{A}$ could be detected in the ${ }^{1} \mathrm{H}$ NMR spectrum and no resonances were observed in the ${ }^{31} \mathrm{P}$ spectrum. Heating $\mathrm{N}_{3} \mathrm{P}(\mathrm{O}) \mathbf{A}$ at $80{ }^{\circ} \mathrm{C}$ in benzene- $d_{6}$ for 30 min results in the observation of signals of $\mathbf{A}$ in the ${ }^{1} \mathrm{H}$ NMR spectrum as well as one major resonance at $\delta 112.7 \mathrm{ppm}$ in the ${ }^{31} \mathrm{P}\left\{{ }^{1} \mathrm{H}\right\}$ spectrum together with some other minor resonances (Figure S5). However, none of these resonances could be unambiguously assigned.

A standard NMR tube was charged with $10 \mathrm{mg}$ of $\mathrm{N}_{3} \mathrm{P}(\mathrm{O}) \mathbf{A}$ and $5 \mathrm{mg}$ acenaphthene as an internal standard. The tube was filled with $0.6 \mathrm{~mL}$ benzene- $d_{6}$ and placed into the NMR spectrometer. All kinetic studies were performed by ${ }^{1} \mathrm{H}$ NMR spectroscopy on a Bruker Avance Neo500 spectrometer $\left({ }^{1} \mathrm{H} 500\right.$ MHz). Temperatures were calibrated with an ethylene glycol thermometer. ${ }^{9}$ Eight-scan spectra were acquired continuously over a period of 3-5 half-lives depending on the temperature. Integrals of the $\mathrm{N}_{3} \mathrm{P}(\mathrm{O}) \mathrm{A}$ bridgehead protons were normalized against the methylene protons of internal standard acenaphthene at $2.99 \mathrm{ppm}$. The integral of the bridgehead protons (A) at 3.72 and $3.75 \mathrm{ppm}$ was evaluated according to a zero-order $\left(\mathrm{A}=\mathrm{A}_{0}-k t\right.$, Figure $\left.\mathrm{S} 20\right)$, first-order $\left(\ln (\mathrm{A})=\ln \left(\mathrm{A}_{0}\right)-k t\right.$, Figure $\mathrm{S} 21)$ and second-order $\left(\mathrm{A}^{-1}-\mathrm{A}_{0}{ }^{-1}=k t\right.$, Figure S22) kinetics. All experiments were performed three times at a given temperature and averaged. The measurements are summarized in Table S1-S2 and the associated Eyring plot is depicted in Figure S23. All error bars were calculated according to total derivatives.

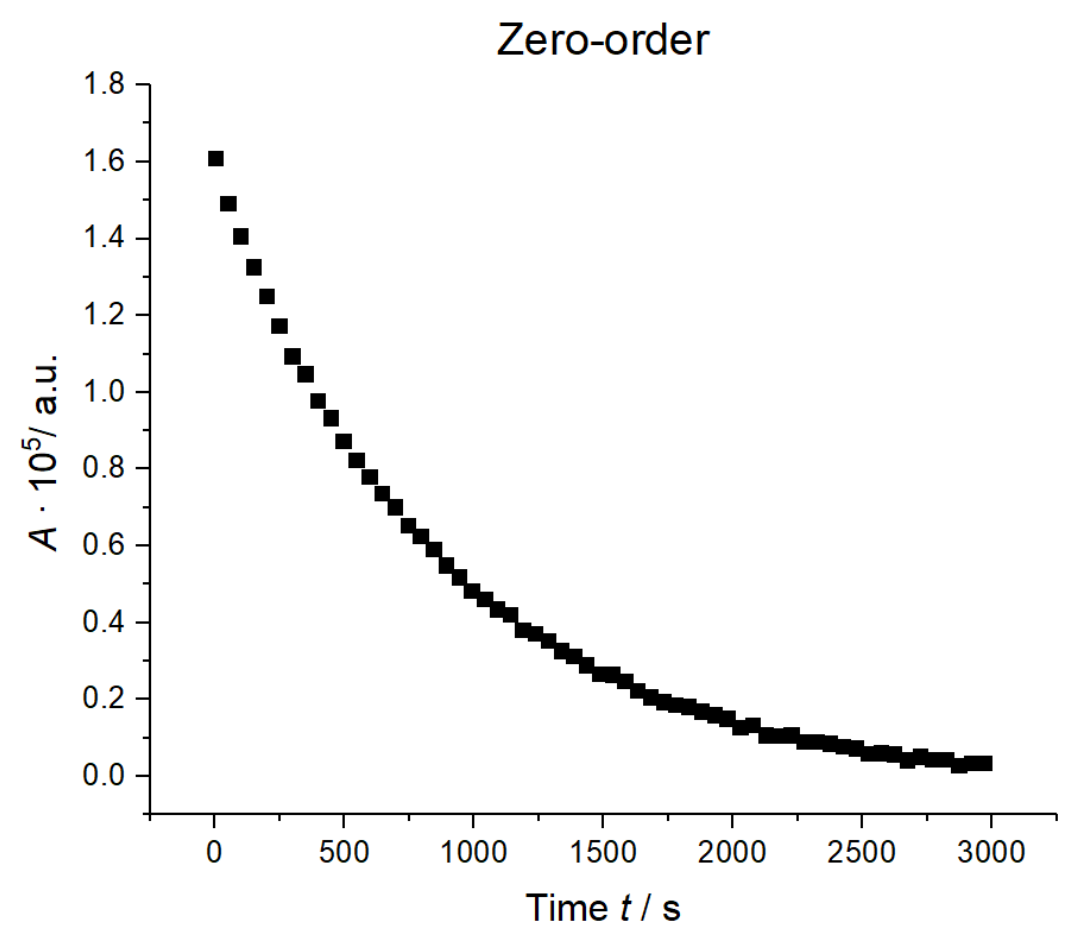

Figure S20: Decay of $\mathrm{N}_{3} \mathrm{P}(\mathrm{O}) \mathrm{A}$ according to a zero-order kinetics $\left(A=A_{0}-k t\right)$ at $60.0^{\circ} \mathrm{C}$. 


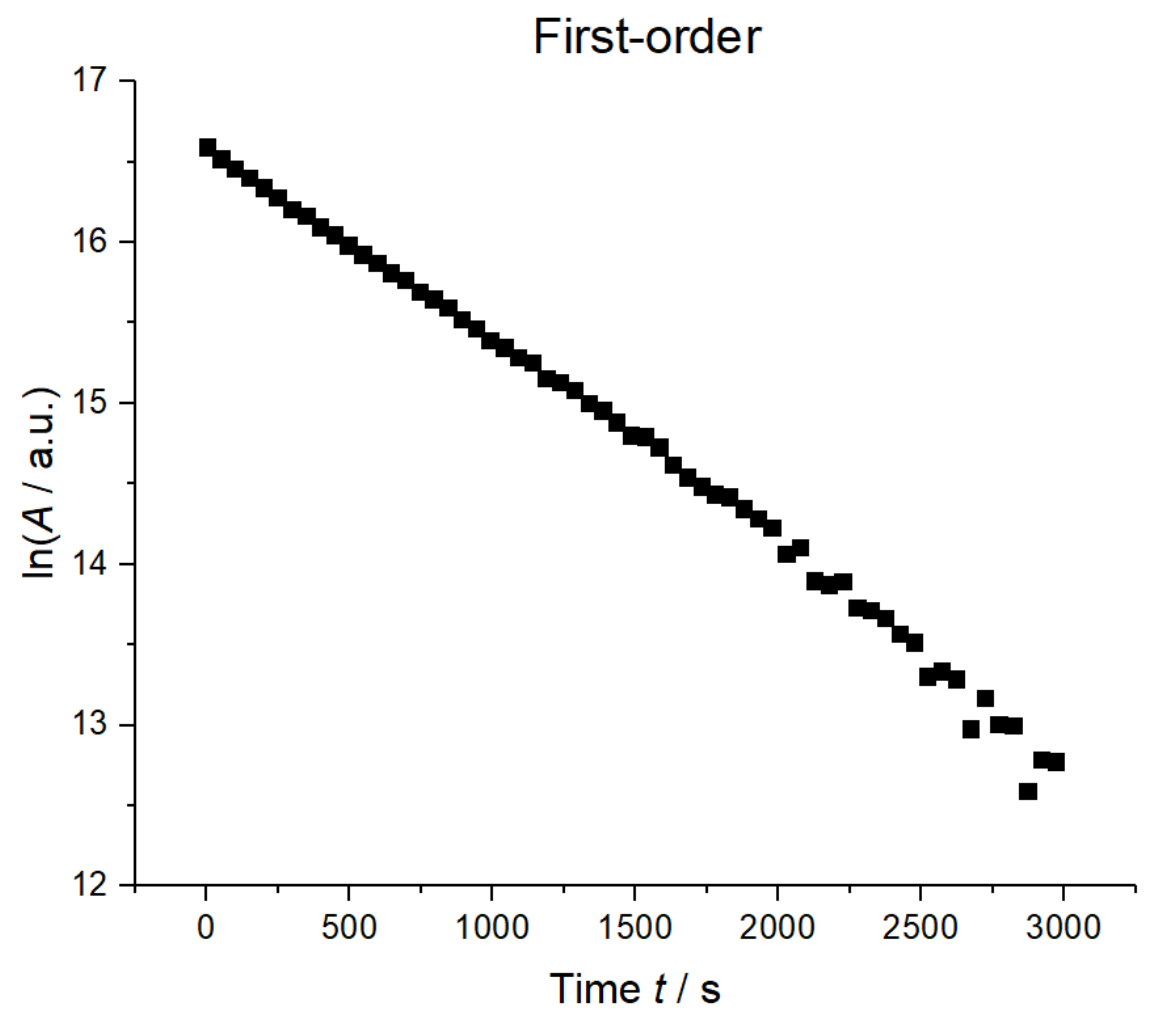

Figure S21: Decay of $\mathrm{N}_{3} \mathrm{P}(\mathrm{O}) \mathrm{A}$ according to a first-order kinetics $\left(\ln (\mathrm{A})=\ln \left(\mathrm{A}_{0}\right)-k t\right)$ at $60.0^{\circ} \mathrm{C}$.

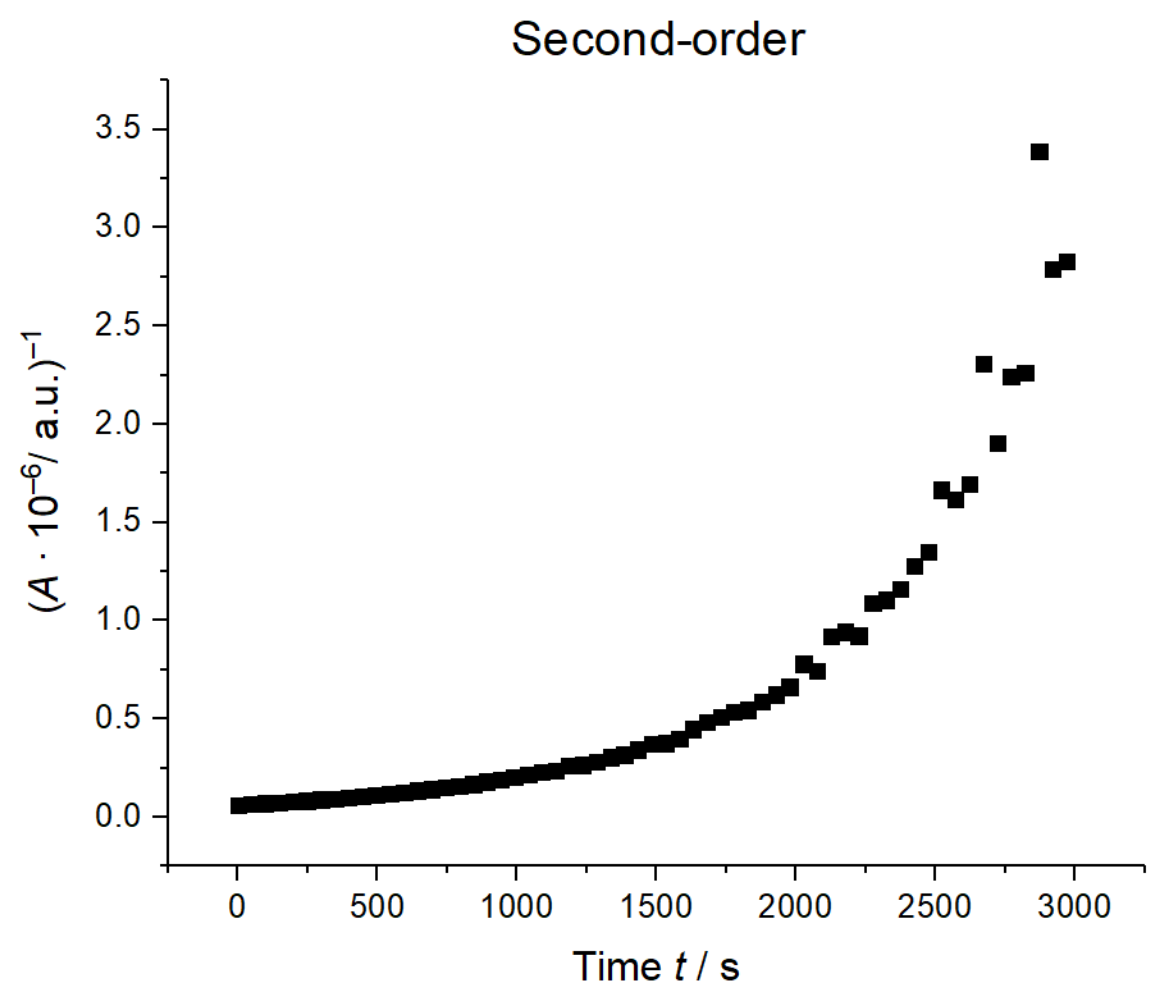

Figure S22: Decay of $\mathrm{N}_{3} \mathrm{P}(\mathrm{O}) \mathrm{A}$ according to a second-order kinetics $\left(\mathrm{A}^{-1}-\mathrm{A}_{0}^{-1}=k t\right) 60.0^{\circ} \mathrm{C}$. 
As only the evaluation according to a first order kinetic profile results in a linear plot, $\mathrm{N}_{3} \mathrm{P}(\mathrm{O}) \mathbf{A}$ decays following first-order kinetics. The experiment was repeated three times.

Table S1: Rate constant $k$ and half-life of the decay of $\mathrm{N}_{3} \mathrm{P}(\mathrm{O}) \mathrm{A}$ according to a first-order kinetics at $60.0^{\circ} \mathrm{C}$.

\begin{tabular}{|c|c|}
\hline Experiment & Rate constant $/ \mathbf{s}^{\mathbf{- 1}}$ \\
\hline$\# 01$ & $(1.29 \pm 0.01) \cdot 10^{-3}$ \\
\hline$\# 02$ & $(1.02 \pm 0.01) \cdot 10^{-3}$ \\
\hline$\# 03$ & $(1.35 \pm 0.03) \cdot 10^{-3}$ \\
\hline average & $(1.22 \pm 0.02) \cdot 10^{-3}$ \\
\hline
\end{tabular}

The same set of experiments was repeated at 52.5, 67.5 and $75.0{ }^{\circ} \mathrm{C}$ and an Eyring plot (Figure S23) prepared based on these data.

Table 2: Rate constants $k$ of the decay of $\mathrm{N}_{3} \mathrm{P}(\mathrm{O}) \mathbf{A}$ according to a first-order kinetics at $25,35,45$ and $55^{\circ} \mathrm{C}$

\begin{tabular}{|c|c|c|c|c|}
\hline $\begin{array}{c}\operatorname{Exp} / \\
T \text { in }{ }^{\circ} \mathrm{C} \\
\end{array}$ & 52.5 & 60.0 & 67.5 & 70.0 \\
\hline$\# 01$ & $(3.45 \pm 0.02) \cdot 10^{-4}$ & $(1.29 \pm 0.01) \cdot 10^{-3}$ & $(3.22 \pm 0.06) \cdot 10^{-3}$ & $(7.40 \pm 0.12) \cdot 10^{-3}$ \\
\hline$\# 02$ & $(3.53 \pm 0.09) \cdot 10^{-4}$ & $(1.02 \pm 0.01) \cdot 10^{-3}$ & $(3.30 \pm 0.03) \cdot 10^{-3}$ & $(8.06 \pm 0.31) \cdot 10^{-3}$ \\
\hline$\# 03$ & $(6.64 \pm 0.09) \cdot 10^{-4}$ & $(1.35 \pm 0.03) \cdot 10^{-3}$ & $(3.07 \pm 0.04) \cdot 10^{-3}$ & $(7.13 \pm 0.29) \cdot 10^{-3}$ \\
\hline average & $(4.54 \pm 0.07) \cdot 10^{-4}$ & $(1.22 \pm 0.02) \cdot 10^{-3}$ & $(3.20 \pm 0.05) \cdot 10^{-3}$ & $(7.53 \pm 0.24) \cdot 10^{-3}$ \\
\hline
\end{tabular}

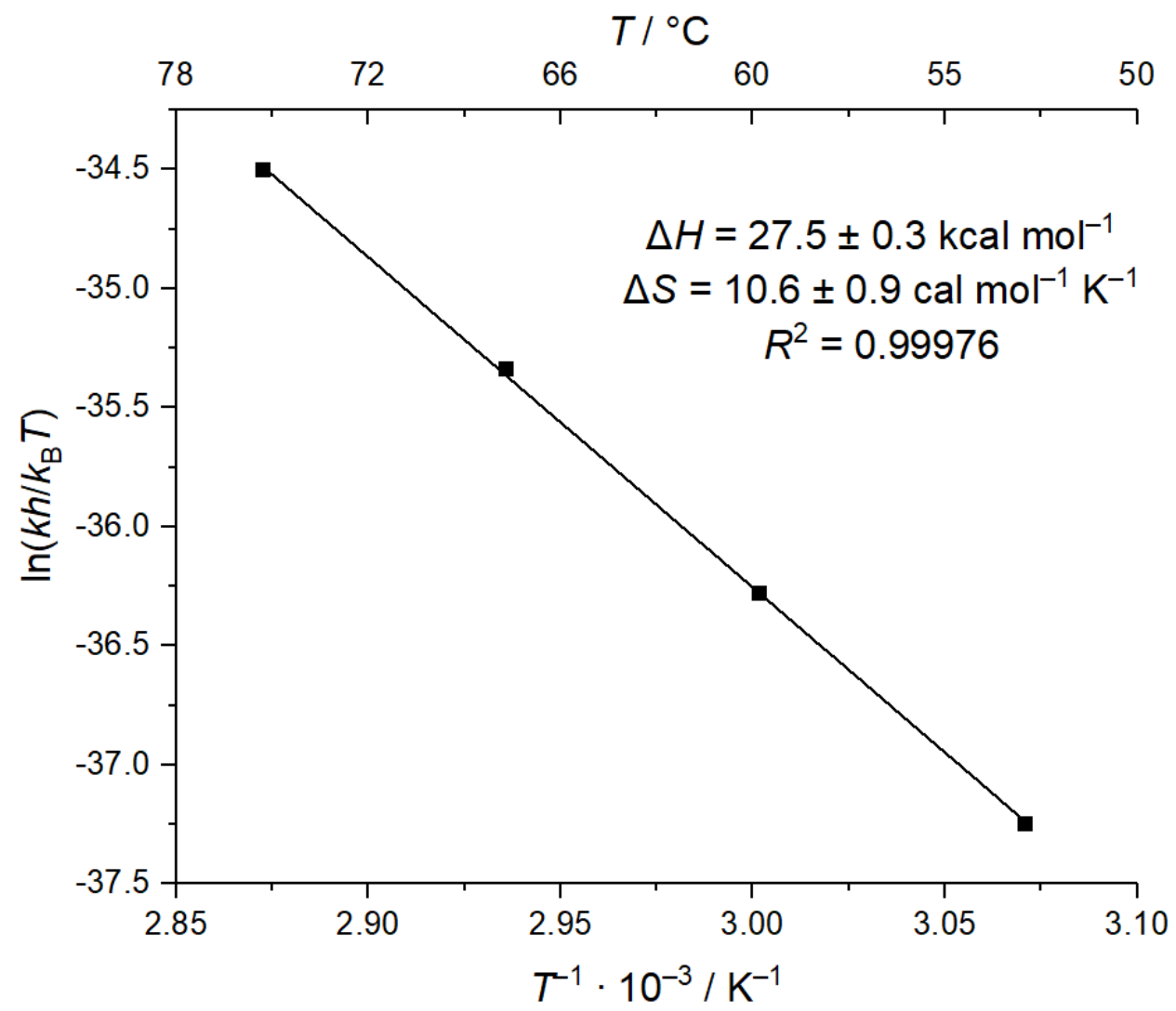

Figure S23: Eyring plot for the decay of $\mathrm{N}_{3} \mathrm{P}(\mathrm{O}) \mathbf{A}$ using rate constants from monitoring $\mathrm{N}_{3} \mathrm{P}(\mathrm{O}) \mathbf{A}$ decay by ${ }^{1} \mathrm{H}$ NMR spectroscopy. 


\section{Molecular Beam Mass Spectrometry (MBMS)}

The molecular beam mass spectrometer (MBMS) apparatus has been previously described elsewhere.,

${ }^{10}$ Briefly, the apparatus consists of two high vacuum chambers designated the source and detection chamber. The source chamber consists of a sample holder suspended in the middle of the vacuum chamber. The sample holder is a ceramic cup directed at a $1 \mathrm{~mm}$ diameter skimmer from the source chamber to the detection chamber. The ceramic cup is loaded with 10 to $15 \mathrm{mg}$ of sample, restrained with a stainless steel screen (98\% open area, Unique Wire Weaving Co.), and resistively heated with Nichrome wire wrapped around the cup. The temperature is monitored with a thermocouple reader, the placement of which on the sample holder may have some effect on the temperature reading. Experience has indicated that temperature readings are generally consistent within $5{ }^{\circ} \mathrm{C}$ between runs. Once gases are evolved from the sample, they pass unimpeded through a $1 \mathrm{~mm}$ diameter skimmer between the source chamber and the detection chamber, creating a molecular beam. The molecular beam is then sent to the entrance of an axially oriented Extrel MAX600 Mass Spectrometer (Extrel Core Mass Spectrometers), where the beam is ionized by EI ( $70 \mathrm{eV})$, mass separated by a quadrupole, and detected by a Faraday cup. The masses of interest are monitored as a function of temperature and are baseline corrected for background signal. Where depicted, literature fragmentation data were taken from the AIST SDBS. ${ }^{11}$

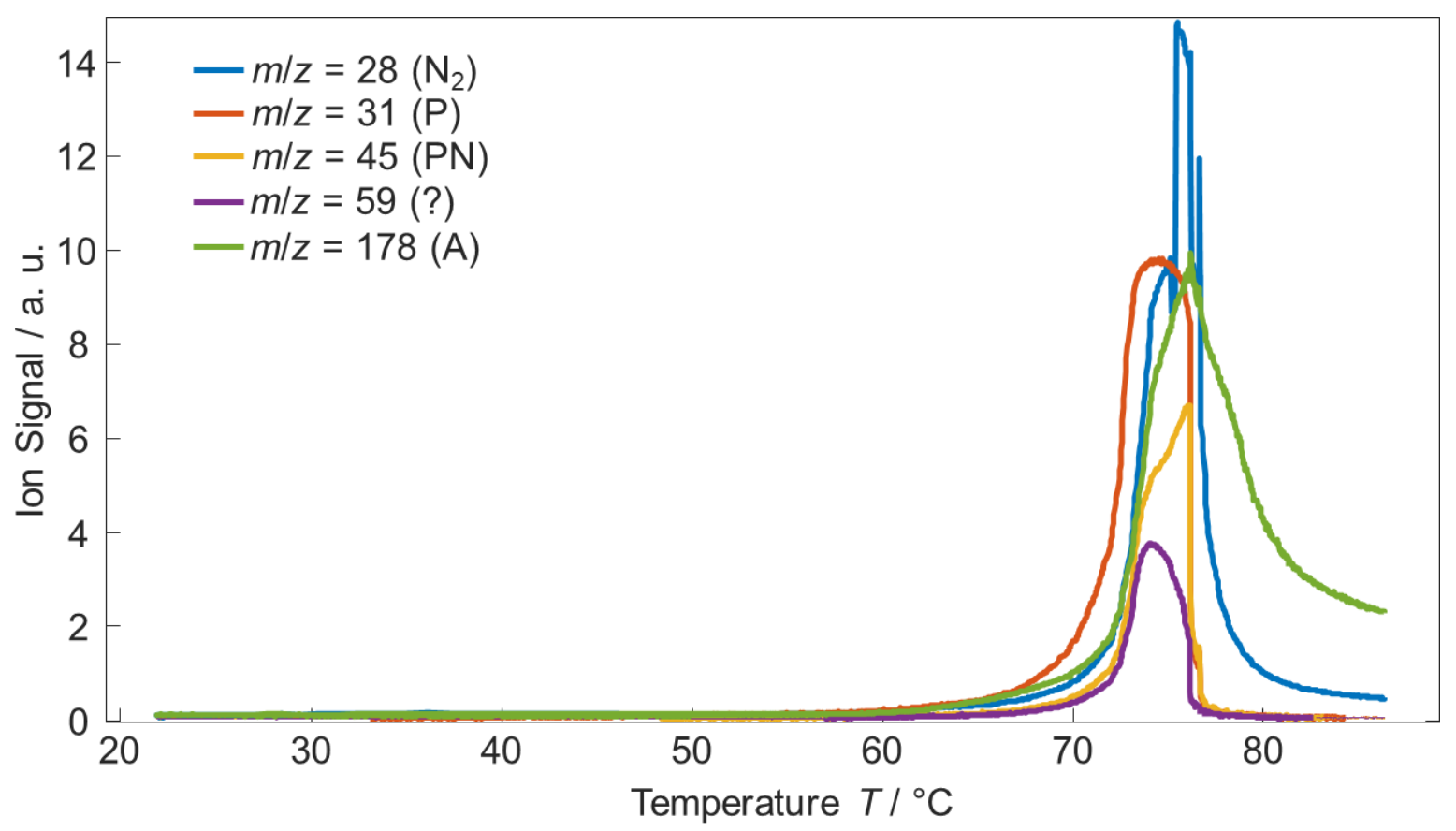

Figure S24: Molecular Beam Mass Spectrum (MBMS) of $\mathrm{N}_{3} \mathrm{P}(\mathrm{O}) \mathrm{A}$ with the major detected decomposition products that were assigned to $\mathrm{N}_{2}{ }^{+}(m / z=28), \mathrm{P}^{+}(m / z=31), \mathrm{PN}^{+}(m / z=45)$, anthracene ${ }^{+}(\mathbf{A}, m / z=178)$ and $\mathrm{CPO}^{+}$ or $\mathrm{PN}_{2}{ }^{+}$at $m / z=59$. 


\section{Decay of Solid $\mathbf{N}_{3} \mathrm{P}(\mathrm{O}) \mathrm{A}$}

Attention: Solid $N_{3} P(O) A$ is potentially explosive and should not be heated!

Solid $\mathrm{N}_{3} \mathrm{P}(\mathrm{O}) \mathbf{A}(10 \mathrm{mg})$ were transferred to a J-Young NMR tube inside the glovebox. The tube was sealed and heated $15 \mathrm{~min}$ at $80{ }^{\circ} \mathrm{C}$ in an oil bath outside the glovebox. The solid turned yellow-brown. The tube was brought back inside the glovebox and a minimum amount of the solids transferred to a vial for IR analysis. To the rest of the solids benzene- $d_{6}$ added for NMR analysis. Note that not all of the solids did dissolve in benzene. ${ }^{1} \mathrm{H}$ NMR analysis only revealed the formation of anthracene and no resonances in the ${ }^{31} \mathrm{P}$ NMR were observed. The solids that did not dissolve in benzene were filtered and washed with acetone under air and analyzed by IR spectroscopy. IR analysis of the solids reveals the formation of anthracene (sharp bands in black spectrum in Figure S25) as well as presumably a new azide containing inorganic species (based on the broad band at $2168 \mathrm{~cm}^{-1}$ in the red spectrum in Figure S25).

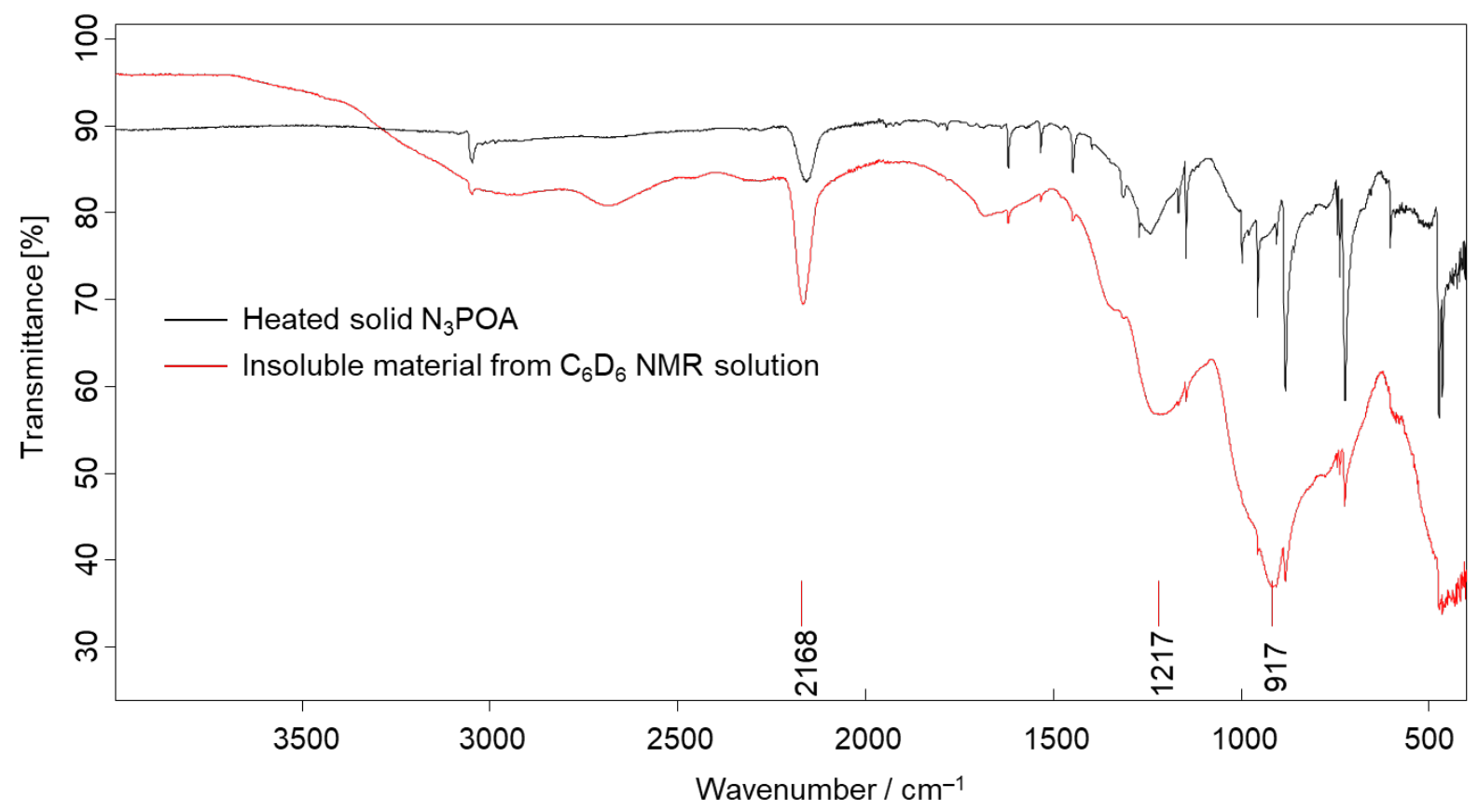

Figure S25: ATR-IR spectrum of heated solid $\mathrm{N}_{3} \mathrm{P}(\mathrm{O}) \mathbf{A}$ (black spectrum) and acetone washed insoluble residues from a deuterated benzene suspension. 


\section{X-Ray Diffraction Studies}

Diffraction-quality, colorless crystals of $\mathrm{N}_{3} \mathrm{P}(\mathrm{O}) \mathbf{A}, \quad \mathrm{Cy}_{3} \mathrm{P}=\mathrm{NP}(\mathrm{O}) \mathbf{A}, \mathrm{Cy}_{3} \mathrm{P}-\mathrm{NP}(\mathbf{A}) \mathrm{O}-\mathrm{B}\left(\mathrm{C}_{6} \mathrm{~F}_{5}\right)_{3}$ and $\mathrm{Cy}_{3} \mathrm{P}-\mathrm{NPO}-\mathrm{B}\left(\mathrm{C}_{6} \mathrm{~F}_{5}\right)_{3}$ were grown at $-20{ }^{\circ} \mathrm{C}$ from saturated solutions as described in the experimental procedure. Low-temperature $\left(-100^{\circ} \mathrm{C}\right)$ diffraction data were collected on a Bruker-AXS X8 Kappa Duo diffractometer with $I \mu S$ micro-sources, coupled to a Photon 3 CPAD detector and a Smart APEX2 CCD detector, respectively, performing $\phi$-and $\omega$-scans. $\mathrm{Cu} K_{\alpha}$ radiation $(\lambda=1.54178 \AA)$ was used for $\mathrm{N}_{3} \mathrm{P}(\mathrm{O}) \mathrm{A}$ and Mo $K_{\alpha}$ radiation $(\lambda=0.71073 \AA)$ was used for the other three structures. The structures were solved by dual-space methods using SHELXT ${ }^{12}$ and refined against $F^{2}$ on all data by full-matrix least squares with SHELXL-2017 ${ }^{13}$ following established refinement strategies. ${ }^{14}$ All non-hydrogen atoms were refined anisotropically. All hydrogen atoms were included into the model at geometrically calculated positions and refined using a riding model. The isotropic displacement parameters of all hydrogen atoms were fixed to 1.2 times the $U$-value of the atoms they are linked to. Details of the data quality and a summary of the residual values of the refinement are listed in Tables S3-S5. All .cif files are available from the CCDC CSD.

$\mathrm{N}_{3} \mathrm{P}(\mathrm{O}) \mathrm{A}$ crystallizes in the monoclinic centrosymmetric space group $P 2_{1} / c$ with two molecules of $\mathrm{N}_{3} \mathrm{P}(\mathrm{O}) \mathrm{A}$ per asymmetric unit. In addition, the asymmetric unit contains one half molecule of highly disordered diethyl ether. This solvent was modelled as disordered over six positions (three of them crystallographically unique); however this model did not lead to a stable refinement. Therefore, SQUEEZE ${ }^{15}$ as implemented in Platon ${ }^{16}$ was used to address the diffuse solvent electron density. SQUEEZE accounted for ca. 80 electrons, which corresponds to just below two $\mathrm{Et}_{2} \mathrm{O}$ molecules per unit cell. This lines up well with the half ether molecule per asymmetric unit that was modelled unsuccessfully as disordered over three independent positions near the crystallographic inversion center. The disorder model is still contained in the SHELXL instruction file as a comment. Since the SHELXL instruction file is part of the CIF file, the attempted solvent disorder can be examined by those interested.

$\mathrm{Cy}_{3} \mathrm{P}=\mathrm{NP}(\mathrm{O}) \mathbf{A}$ crystallizes in the monoclinic space group $P 2_{1} / n$ with one molecule of $\mathrm{Cy}_{3} \mathrm{P}=\mathrm{NP}(\mathrm{O}) \mathbf{A}$ and one molecule of diethyl ether in the asymmetric unit. The molecules exhibit no disorder.

$\mathrm{Cy}_{3} \mathrm{P}-\mathrm{NP}(\mathrm{A}) \mathrm{O}-\mathrm{B}\left(\mathrm{C}_{6} \mathrm{~F}_{5}\right)_{3}$ crystallizes in the triclinic space group $P 1$ with two molecules of $\mathrm{Cy}_{3} \mathrm{P}-\mathrm{NP}(\mathbf{A}) \mathrm{O}-\mathrm{B}\left(\mathrm{C}_{6} \mathrm{~F}_{5}\right)_{3}$ and four molecules of diethyl ether in the asymmetric unit. Two of the four diethyl ethers were refined as disordered over two positions with the help of similarity restraints on 1-2 and 1-3 distances and displacement parameters. The disorder ratios were refined freely and converged at $0.558(5)$ and $0.661(4)$.

$\mathrm{Cy}_{3} \mathrm{P}-\mathrm{NPO}-\mathrm{B}\left(\mathrm{C}_{6} \mathrm{~F}_{5}\right)_{3}$ crystallizes in the monoclinic space group $C 2 / c$ with one molecule of $\mathrm{Cy}_{3} \mathrm{P}-\mathrm{NPO}-\mathrm{B}\left(\mathrm{C}_{6} \mathrm{~F}_{5}\right)_{3}$ in the asymmetric unit. The molecule exhibits no disorder. 
Table S3: Crystallographic data for $\mathrm{N}_{3} \mathrm{P}(\mathrm{O}) \mathrm{A}$.

\begin{tabular}{|c|c|}
\hline CSD identification code & 2113855 \\
\hline Reciprocal net code & P8_20123 \\
\hline Empirical formula & $\mathrm{C}_{14} \mathrm{H}_{10} \mathrm{~N}_{3} \mathrm{OP}$ \\
\hline Formula weight $\left(\mathrm{g} \mathrm{mol}^{-1}\right)$ & 267.22 \\
\hline Temperature $(\mathrm{K})$ & $100(2)$ \\
\hline Wavelength $(\AA)$ & 1.54178 \\
\hline Crystal system & Monoclinic \\
\hline \multirow[t]{2}{*}{ Space group } & $P 2_{1} / c$ \\
\hline & $a=7.1500(3), \alpha=90$ \\
\hline \multirow[t]{2}{*}{ Unit cell dimensions $\left(\AA,{ }^{\circ}\right)$} & $b=20.8990(7), \beta=91.204(2)$ \\
\hline & $c=18.2161(6), \gamma=90$ \\
\hline Volume $\left(\AA^{3}\right)$ & $2721.39(17)$ \\
\hline$Z$ & 8 \\
\hline Density (calc., $\mathrm{g} \mathrm{cm}^{-3}$ ) & 1.304 \\
\hline Absorption coefficient $\left(\mathrm{mm}^{-1}\right)$ & 1.754 \\
\hline$F(000)$ & 1104 \\
\hline Crystal size $\left(\mathrm{mm}^{3}\right)$ & $0.230 \times 0.015 \times 0.010$ \\
\hline Theta range for data collection $\left(^{\circ}\right)$ & 3.219 to 75.352 \\
\hline Index ranges & $-8 \leq \mathrm{h} \leq 7,-24 \leq \mathrm{k} \leq 26,-22 \leq 1 \leq 22$ \\
\hline Reflections collected & 34065 \\
\hline Independent reflections, $R_{\text {int }}$ & $5566,0.0771$ \\
\hline Completeness to $\Theta_{\max }(\%)$ & 100.0 \\
\hline Absorption correction & Semi-empirical from equivalents \\
\hline Max. and min. transmission & 0.5542 and 0.4355 \\
\hline Refinement method & Full-matrix least-squares on $F^{2}$ \\
\hline Data / restraints / parameters & $5566 / 0 / 343$ \\
\hline Goodness-of-fit on $F^{2}$ & 1.049 \\
\hline Final $R$ indices $[I>2 \sigma(I)]$ & $R_{1}=0.0432, \omega R_{2}=0.1112$ \\
\hline$R$ indices (all data) & $R_{1}=0.0602, \omega R_{2}=0.1228$ \\
\hline Largest diff. peak and hole $\left(e \AA^{-3}\right)$ & 0.312 and -0.484 \\
\hline
\end{tabular}


Table S4: Crystallographic data for $\mathrm{Cy}_{3} \mathrm{P}=\mathrm{NP}(\mathrm{O}) \mathbf{A}$.

\begin{tabular}{|c|c|}
\hline CSD identification code & 2113617 \\
\hline Reciprocal net code & X8_21042 \\
\hline Empirical formula & $\mathrm{C}_{36} \mathrm{H}_{53} \mathrm{NO}_{2} \mathrm{P}_{2}$ \\
\hline Formula weight $\left(\mathrm{g} \mathrm{mol}^{-1}\right)$ & 597.73 \\
\hline Temperature $(\mathrm{K})$ & $100(2)$ \\
\hline Wavelength $(\AA)$ & 0.71073 \\
\hline Crystal system & Monoclinic \\
\hline \multirow[t]{2}{*}{ Space group } & $P 2_{1} / n$ \\
\hline & $a=11.6601(5), \alpha=90$ \\
\hline \multirow[t]{2}{*}{ Unit cell dimensions $\left(\AA,{ }^{\circ}\right)$} & $b=18.2594(7), \beta=91.9110(10)$ \\
\hline & $c=15.1712(6), \gamma=90$ \\
\hline Volume $\left(\AA^{3}\right)$ & $3228.3(2)$ \\
\hline$Z$ & 4 \\
\hline Density (calc., $\mathrm{g} \mathrm{cm}^{-3}$ ) & 1.222 \\
\hline Absorption coefficient $\left(\mathrm{mm}^{-1}\right)$ & 0.167 \\
\hline$F(000)$ & 1288 \\
\hline Crystal size $\left(\mathrm{mm}^{3}\right)$ & $0.230 \times 0.140 \times 0.125$ \\
\hline Theta range for data collection $\left(^{\circ}\right)$ & 1.746 to 31.511 \\
\hline Index ranges & $-17 \leq \mathrm{h} \leq 17,-26 \leq \mathrm{k} \leq 24,-22 \leq 1 \leq 22$ \\
\hline Reflections collected & 122510 \\
\hline Independent reflections, $R_{\mathrm{int}}$ & $10744,0.0517$ \\
\hline Completeness to $\Theta_{\max }(\%)$ & 100.0 \\
\hline Absorption correction & Semi-empirical from equivalents \\
\hline Max. and min. transmission & 0.7462 and 0.6662 \\
\hline Refinement method & Full-matrix least-squares on $F^{2}$ \\
\hline Data / restraints / parameters & 10744 / 0 / 372 \\
\hline Goodness-of-fit on $F^{2}$ & 1.037 \\
\hline Final $R$ indices $[I>2 \sigma(I)]$ & $R_{1}=0.0345, \omega R_{2}=0.0874$ \\
\hline$R$ indices (all data) & $R_{1}=0.0423, \omega R_{2}=0.0921$ \\
\hline Largest diff. peak and hole $\left(e \AA^{-3}\right)$ & 0.453 and -0.352 \\
\hline
\end{tabular}


Table S5: Crystallographic data for $\mathrm{Cy}_{3} \mathrm{P}-\mathrm{NP}(\mathrm{A}) \mathrm{O}-\mathrm{B}\left(\mathrm{C}_{6} \mathrm{~F}_{5}\right)_{3}$.

\begin{tabular}{|c|c|}
\hline CSD identification code & 2113618 \\
\hline Reciprocal net code & X8_21037 \\
\hline Empirical formula & $\mathrm{C}_{58} \mathrm{H}_{63} \mathrm{BF}_{15} \mathrm{NO}_{3} \mathrm{P}_{2}$ \\
\hline Formula weight $\left(\mathrm{g} \mathrm{mol}^{-1}\right)$ & 1179.84 \\
\hline Temperature $(\mathrm{K})$ & $100(2)$ \\
\hline Wavelength $(\AA)$ & 0.71073 \\
\hline Crystal system & Triclinic \\
\hline \multirow[t]{2}{*}{ Space group } & $P 1$ \\
\hline & $a=12.1132(6), \alpha=72.9230(10)$ \\
\hline \multirow[t]{2}{*}{ Unit cell dimensions $\left(\AA,{ }^{\circ}\right)$} & $b=20.5429(9), \beta=78.6680(10)$ \\
\hline & $c=23.5935(10), \gamma=89.9210(10)$ \\
\hline Volume $\left(\AA^{3}\right)$ & $5492.8(4)$ \\
\hline$Z$ & 4 \\
\hline Density (calc., $\mathrm{g} \mathrm{cm}^{-3}$ ) & 1.427 \\
\hline Absorption coefficient $\left(\mathrm{mm}^{-1}\right)$ & 0.176 \\
\hline$F(000)$ & 2448 \\
\hline Crystal size $\left(\mathrm{mm}^{3}\right)$ & $0.380 \times 0.265 \times 0.205$ \\
\hline Theta range for data collection $\left(^{\circ}\right)$ & 1.039 to 30.526 \\
\hline Index ranges & $-17 \leq \mathrm{h} \leq 17,-29 \leq \mathrm{k} \leq 29,-33 \leq 1 \leq 33$ \\
\hline Reflections collected & 202912 \\
\hline Independent reflections, $R_{\mathrm{int}}$ & $33559,0.0474$ \\
\hline Completeness to $\Theta_{\max }(\%)$ & 99.9 \\
\hline Absorption correction & Semi-empirical from equivalents \\
\hline Max. and min. transmission & 0.7461 and 0.7121 \\
\hline Refinement method & Full-matrix least-squares on $F^{2}$ \\
\hline Data / restraints / parameters & 33559 / 3024 / 1544 \\
\hline Goodness-of-fit on $F^{2}$ & 1.034 \\
\hline Final $R$ indices $[I>2 \sigma(I)]$ & $R_{1}=0.0456, \omega R_{2}=0.1234$ \\
\hline$R$ indices (all data) & $R_{1}=0.0695, \omega R_{2}=0.1381$ \\
\hline Largest diff. peak and hole $\left(e \AA^{-3}\right)$ & 0.530 and -0.585 \\
\hline
\end{tabular}


Table S6: Crystallographic data for $\mathrm{Cy}_{3} \mathrm{P}-\mathrm{NPO}-\mathrm{B}\left(\mathrm{C}_{6} \mathrm{~F}_{5}\right)_{3}$.

\begin{tabular}{|c|c|}
\hline CSD identification code & 2113616 \\
\hline Reciprocal net code & P8_21108 \\
\hline Empirical formula & $\mathrm{C}_{36} \mathrm{H}_{33} \mathrm{BF}_{15} \mathrm{NOP}_{2}$ \\
\hline Formula weight $\left(\mathrm{g} \mathrm{mol}^{-1}\right)$ & 853.38 \\
\hline Temperature $(\mathrm{K})$ & $101(2)$ \\
\hline Wavelength $(\AA)$ & 0.71073 \\
\hline Crystal system & Monoclinic \\
\hline \multirow[t]{2}{*}{ Space group } & $C 2 / c$ \\
\hline & $a=28.1151(10), \alpha=90$ \\
\hline \multirow[t]{2}{*}{ Unit cell dimensions $\left(\AA,{ }^{\circ}\right)$} & $b=13.2645(4), \beta=125.0510(10)$ \\
\hline & $c=23.6665(8), \gamma=90$ \\
\hline Volume $\left(\AA^{3}\right)$ & $7225.3(4)$ \\
\hline$Z$ & 8 \\
\hline Density (calc., $\mathrm{g} \mathrm{cm}^{-3}$ ) & 1.569 \\
\hline Absorption coefficient $\left(\mathrm{mm}^{-1}\right)$ & 0.231 \\
\hline$F(000)$ & 3472 \\
\hline Crystal size $\left(\mathrm{mm}^{3}\right)$ & $0.380 \times 0.195 \times 0.125$ \\
\hline Theta range for data collection $\left(^{\circ}\right)$ & 1.770 to 33.216 \\
\hline Index ranges & $-43 \leq \mathrm{h} \leq 43,-20 \leq \mathrm{k} \leq 20,-36 \leq 1 \leq 36$ \\
\hline Reflections collected & 229148 \\
\hline Independent reflections, $R_{\text {int }}$ & $13862,0.0600$ \\
\hline Completeness to $\Theta_{\max }(\%)$ & 100.0 \\
\hline Absorption correction & Semi-empirical from equivalents \\
\hline Max. and min. transmission & 0.7465 and 0.7017 \\
\hline Refinement method & Full-matrix least-squares on $F^{2}$ \\
\hline Data / restraints / parameters & $13862 / 0 / 505$ \\
\hline Goodness-of-fit on $F^{2}$ & 1.037 \\
\hline Final $R$ indices $[I>2 \sigma(I)]$ & $R_{1}=0.0371, \omega R_{2}=0.0943$ \\
\hline$R$ indices (all data) & $R_{1}=0.0487, \omega R_{2}=0.1018$ \\
\hline Largest diff. peak and hole $\left(e \AA^{-3}\right)$ & 0.544 and -0.425 \\
\hline
\end{tabular}




\section{Computational Studies}

Unless otherwise indicated, all calculations were performed with the Gaussian 16 Rev C.01 quantum chemistry package. All geometries were optimized at PBE0-D3(BJ)/cc-pVTZ level of theory. ${ }^{17-20}$ In all cases, computed electronic energies were corrected for thermal energy to obtain the corresponding free energy (all free energies reported at $298.15 \mathrm{~K}$ within this SI). To disclose the nature of all stationary points we computed the corresponding frequencies (Nimag $=0$ for minima and 1 for transition states). All transition states were also confirmed by PBE0-D3(BJ)/cc-pVTZ IRC computations employing Gaussian 16. All electronic energies were augmented with higher level DLPNO-CCSD(T)/cc-pVTZ energies with TightPNO settings. ${ }^{21}$

Cartesian coordinates (in $\AA$ ) and energies in (Hartree)
$\mathbf{A}\left(D_{2 \mathrm{~h}}\right)$
$\begin{array}{lrrr}\mathrm{C} & -0.000000 & -1.405559 & 0.000000 \\ \mathrm{H} & -0.000000 & 2.501134 & 2.476017 \\ \mathrm{C} & -0.000000 & -0.722400 & 1.223935 \\ \mathrm{H} & -0.000000 & 1.249925 & 4.614267 \\ \mathrm{C} & -0.000000 & 0.722400 & 1.223935\end{array}$
$\begin{array}{llll}\mathrm{H} & -0.000000 & -1.249925 & 4.614267\end{array}$
$\begin{array}{llll}\mathrm{C} & -0.000000 & 1.405559 & -0.000000\end{array}$
$\mathrm{H} \quad-0.000000 \quad-2.501134 \quad 2.476017$
C $\quad-0.000000 \quad 0.722400 \quad-1.223935$
$\begin{array}{llll}\mathrm{H} & -0.000000 & 2.501134 & -2.476017\end{array}$
$\begin{array}{llll}\mathrm{C} & -0.000000 & -0.722400 & -1.223935\end{array}$
$\begin{array}{llll}\mathrm{H} & -0.000000 & 1.249925 & -4.614267\end{array}$
$\begin{array}{llll}\mathrm{C} & -0.000000 & 1.408446 & 2.480280\end{array}$
$\begin{array}{llll}\mathrm{H} & -0.000000 & -1.249925 & -4.614267\end{array}$
$\begin{array}{llll}\mathrm{C} & -0.000000 & 0.714121 & 3.662715\end{array}$
$\begin{array}{llll}\mathrm{H} & -0.000000 & -2.501134 & -2.476017\end{array}$
$\begin{array}{llll}\mathrm{C} & -0.000000 & -0.714121 & 3.662715\end{array}$
$\begin{array}{llll}\mathrm{H} & -0.000000 & 2.498816 & -0.000000\end{array}$
$\begin{array}{llll}\mathrm{C} & -0.000000 & -1.408446 & 2.480280\end{array}$
$\begin{array}{llll}\mathrm{H} & -0.000000 & -2.498816 & 0.000000\end{array}$
$\begin{array}{llll}\mathrm{C} & -0.000000 & 1.408446 & -2.480280\end{array}$
$\begin{array}{llll}\text { C } & -0.000000 & 0.714121 & -3.662715\end{array}$
$\begin{array}{llll}\mathrm{C} & -0.000000 & -0.714121 & -3.662715\end{array}$
$\begin{array}{llll}\text { C } & -0.000000 & -1.408446 & -2.480280\end{array}$
$E=-539.6167286$
Zero-point correction $=0.194035$
Thermal correction to Energy $=0.203449$
Thermal correction to Enthalpy $=0.204393$
Thermal correction to Gibbs Free Energy $=0.160588$
$\mathrm{E}[\mathrm{DLPNO}-\mathrm{CCSD}(\mathrm{T}) / \mathrm{cc}-\mathrm{pVTZ}]=-538.4969642$ 


$\begin{array}{lrrr}\text { Cyc-ONPA }\left(C_{\mathrm{s}}\right) & & \\ & & & \\ \mathrm{C} & 0.330609 & 0.011269 & 1.236090 \\ \mathrm{H} & -0.795601 & 2.354366 & -2.487420 \\ \mathrm{C} & -0.306378 & 1.265762 & 0.700988 \\ \mathrm{H} & -1.727705 & 4.272822 & -1.230476 \\ \mathrm{C} & -0.306378 & 1.265762 & -0.700988 \\ \mathrm{H} & -1.727705 & 4.272822 & 1.230476 \\ \mathrm{C} & 0.330609 & 0.011269 & -1.236090 \\ \mathrm{H} & -0.795601 & 2.354366 & 2.487420 \\ \mathrm{C} & -0.410243 & -1.182415 & -0.700854 \\ \mathrm{H} & -0.980370 & -2.230659 & -2.487252 \\ \mathrm{C} & -0.410243 & -1.182415 & 0.700854 \\ \mathrm{H} & -2.066240 & -4.066671 & -1.230523 \\ \mathrm{C} & -0.806457 & 2.347892 & -1.404246 \\ \mathrm{H} & -2.066240 & -4.066671 & 1.230523 \\ \mathrm{C} & -1.323934 & 3.422441 & -0.695104 \\ \mathrm{H} & -0.980370 & -2.230659 & 2.487252 \\ \mathrm{C} & -1.323934 & 3.422441 & 0.695104 \\ \mathrm{H} & 0.588186 & 0.001866 & -2.289939 \\ \mathrm{C} & -0.806457 & 2.347892 & 1.404246 \\ \mathrm{H} & 0.588186 & 0.001866 & 2.289939 \\ \mathrm{C} & -0.993189 & -2.221835 & -1.404116 \\ \mathrm{C} & -1.596003 & -3.251251 & -0.695001 \\ \mathrm{C} & -1.596003 & -3.251251 & 0.695001 \\ \mathrm{C} & -0.993189 & -2.221835 & 1.404116 \\ \mathrm{P} & 1.728573 & -0.026246 & -0.000000 \\ \mathrm{O} & 2.813920 & -1.129707 & -0.000000 \\ \mathrm{~N} & 3.177208 & 0.625055 & -0.000000\end{array}$

$E=-1010.0935786$

Zero-point correction $=0.204611$

Thermal correction to Energy $=0.217126$

Thermal correction to Enthalpy $=0.218071$

Thermal correction to Gibbs Free Energy $=0.165651$

[DLPNO-CCSD $(\mathrm{T}) / \mathrm{cc}-\mathrm{pVTZ}]=-1009.0859480$

\section{ONPA $\left(C_{\mathrm{s}}\right)$}

$\begin{array}{lrrr}\mathrm{C} & 0.474161 & 1.377008 & -0.000000 \\ \mathrm{H} & -0.492373 & -2.477694 & 2.292235 \\ \mathrm{C} & 0.738461 & 0.496975 & 1.206362 \\ \mathrm{H} & 1.054763 & -1.961708 & 4.157539 \\ \mathrm{C} & -0.007306 & -0.683235 & 1.223808 \\ \mathrm{H} & 2.392779 & 0.109168 & 4.122230 \\ \mathrm{C} & -0.879468 & -0.881590 & -0.000000 \\ \mathrm{H} & 2.187180 & 1.695143 & 2.228809 \\ \mathrm{C} & -0.007306 & -0.683235 & -1.223808 \\ \mathrm{H} & -0.492373 & -2.477694 & -2.292235 \\ \mathrm{C} & 0.738461 & 0.496975 & -1.206362 \\ \mathrm{H} & 1.054763 & -1.961708 & -4.157539\end{array}$




$\begin{array}{lrrr}\mathrm{C} & 0.093023 & -1.565647 & 2.281418 \\ \mathrm{H} & 2.392779 & 0.109168 & -4.122230 \\ \mathrm{C} & 0.965189 & -1.274112 & 3.325792 \\ \mathrm{H} & 2.187180 & 1.695143 & -2.228809 \\ \mathrm{C} & 1.718375 & -0.111652 & 3.304097 \\ \mathrm{H} & -1.456168 & -1.802579 & -0.000000 \\ \mathrm{C} & 1.607071 & 0.779751 & 2.241005 \\ \mathrm{H} & 1.113780 & 2.258785 & 0.000000 \\ \mathrm{C} & 0.093023 & -1.565647 & -2.281418 \\ \mathrm{C} & 0.965189 & -1.274112 & -3.325792 \\ \mathrm{C} & 1.718375 & -0.111652 & -3.304097 \\ \mathrm{C} & 1.607071 & 0.779751 & -2.241005 \\ \mathrm{P} & -1.919595 & 0.636026 & -0.000000 \\ \mathrm{~N} & -0.937055 & 1.836596 & -0.000000 \\ \mathrm{O} & -3.386675 & 0.578355 & -0.000000\end{array}$

$\mathrm{E}=-1010.2081621$

Zero-point correction $=0.207282$

Thermal correction to Energy $=0.219193$

Thermal correction to Enthalpy $=0.220137$

Thermal correction to Gibbs Free Energy $=0.169141$

[DLPNO-CCSD $(\mathrm{T}) / \mathrm{cc}-\mathrm{pVTZ}]=-1009.1995262$

\section{$\mathbf{N}_{3} \mathbf{P}(\mathbf{O}) \mathbf{A}\left(C_{\mathrm{s}}\right)$}

$\begin{array}{lrrr}\mathrm{C} & -0.059635 & 0.166721 & 1.230610 \\ \mathrm{H} & 2.210454 & -1.095407 & -2.486346 \\ \mathrm{C} & 1.184960 & -0.488303 & 0.700429 \\ \mathrm{H} & 4.082623 & -2.121010 & -1.230443 \\ \mathrm{C} & 1.184960 & -0.488303 & -0.700429 \\ \mathrm{H} & 4.082623 & -2.121010 & 1.230443 \\ \mathrm{C} & -0.059635 & 0.166721 & -1.230610 \\ \mathrm{H} & 2.210454 & -1.095407 & 2.486346 \\ \mathrm{C} & -0.110353 & 1.576787 & -0.700208 \\ \mathrm{H} & -0.203749 & 2.763842 & -2.486684 \\ \mathrm{C} & -0.110353 & 1.576787 & 0.700208 \\ \mathrm{H} & -0.302212 & 4.896097 & -1.230256 \\ \mathrm{C} & 2.216125 & -1.082096 & -1.402961 \\ \mathrm{H} & -0.302212 & 4.896097 & 1.230256 \\ \mathrm{C} & 3.261469 & -1.661265 & -0.694343 \\ \mathrm{H} & -0.203749 & 2.763842 & 2.486684 \\ \mathrm{C} & 3.261469 & -1.661265 & 0.694343 \\ \mathrm{H} & -0.268913 & 0.039138 & -2.288323 \\ \mathrm{C} & 2.216125 & -1.082096 & 1.402961 \\ \mathrm{H} & -0.268913 & 0.039138 & 2.288323 \\ \mathrm{C} & -0.188685 & 2.763272 & -1.403433 \\ \mathrm{C} & -0.248594 & 3.956523 & -0.694252 \\ \mathrm{C} & -0.248594 & 3.956523 & 0.694252 \\ \mathrm{C} & -0.188685 & 2.763272 & 1.403433 \\ \mathrm{P} & -1.286830 & -0.537167 & 0.000000 \\ \mathrm{O} & -2.708173 & -0.144564 & 0.000000 \\ \mathrm{~N} & -1.050133 & -2.234653 & 0.000000\end{array}$


$\begin{array}{llll}\mathrm{N} & -2.055721 & -2.935122 & 0.000000 \\ \mathrm{~N} & -2.914614 & -3.653912 & 0.000000\end{array}$

$\mathrm{E}=-1119.6208165$

Zero-point correction $=0.216013$

Thermal correction to Energy $=0.230371$

Thermal correction to Enthalpy $=0.231315$

Thermal correction to Gibbs Free Energy $=0.174005$

[DLPNO-CCSD $(\mathrm{T}) / \mathrm{cc}-\mathrm{pVTZ}]=-1118.5209577$

$\mathbf{N}_{3} \mathbf{P}(\mathbf{O}) \mathbf{A} \_2\left(C_{\mathrm{s}}\right)$

$\begin{array}{lrrr}\mathrm{C} & -0.236708 & 0.261232 & 1.232101 \\ \mathrm{H} & 1.470140 & -1.697679 & -2.486630 \\ \mathrm{C} & 0.706711 & -0.779362 & 0.701448 \\ \mathrm{H} & 2.870023 & -3.307546 & -1.230372 \\ \mathrm{C} & 0.706711 & -0.779362 & -0.701448 \\ \mathrm{H} & 2.870023 & -3.307546 & 1.230372 \\ \mathrm{C} & -0.236708 & 0.261232 & -1.232101 \\ \mathrm{H} & 1.470140 & -1.697679 & 2.486630 \\ \mathrm{C} & 0.199221 & 1.601761 & -0.700205 \\ \mathrm{H} & 0.511611 & 2.750713 & -2.486706 \\ \mathrm{C} & 0.199221 & 1.601761 & 0.700205 \\ \mathrm{H} & 1.144050 & 4.789427 & -1.230253 \\ \mathrm{C} & 1.477418 & -1.688679 & -1.403185 \\ \mathrm{H} & 1.144050 & 4.789427 & 1.230253 \\ \mathrm{C} & 2.258554 & -2.592175 & -0.694609 \\ \mathrm{H} & 0.511611 & 2.750713 & 2.486706 \\ \mathrm{C} & 2.258554 & -2.592175 & 0.694609 \\ \mathrm{H} & -0.474239 & 0.215717 & -2.290647 \\ \mathrm{C} & 1.477418 & -1.688679 & 1.403185 \\ \mathrm{H} & -0.474239 & 0.215717 & 2.290647 \\ \mathrm{C} & 0.527289 & 2.744637 & -1.403492 \\ \mathrm{C} & 0.876024 & 3.887272 & -0.694264 \\ \mathrm{C} & 0.876024 & 3.887272 & 0.694264 \\ \mathrm{C} & 0.527289 & 2.744637 & 1.403492 \\ \mathrm{P} & -1.642236 & 0.028961 & 0.000000 \\ \mathrm{O} & -2.800596 & 0.932810 & 0.000000 \\ \mathrm{~N} & -2.214346 & -1.575195 & 0.000000 \\ \mathrm{~N} & -1.548855 & -2.600364 & 0.000000 \\ \mathrm{~N} & -1.070444 & -3.614894 & 0.000000\end{array}$

$\mathrm{E}=-1119.6186116$

Zero-point correction $=0.216124$

Thermal correction to Energy $=0.230352$

Thermal correction to Enthalpy $=0.231296$

Thermal correction to Gibbs Free Energy $=0.174774$

[DLPNO-CCSD $(\mathrm{T}) / \mathrm{cc}-\mathrm{pVTZ}]=-1118.5183251$

\section{Complex $\left(C_{1}\right)$}




$\begin{array}{lrrr}\mathrm{C} & 0.551951 & -1.738719 & 0.679656 \\ \mathrm{H} & -1.986481 & 0.330484 & -2.533409 \\ \mathrm{C} & -0.655717 & -1.537142 & 0.017733 \\ \mathrm{H} & -4.013936 & -0.851564 & -1.813034 \\ \mathrm{C} & -0.704488 & -0.616796 & -1.079296 \\ \mathrm{H} & -3.927308 & -2.465683 & 0.067398 \\ \mathrm{C} & 0.460164 & 0.056348 & -1.451653 \\ \mathrm{H} & -1.809686 & -2.894620 & 1.238671 \\ \mathrm{C} & 1.673496 & -0.157443 & -0.792313 \\ \mathrm{H} & 2.829415 & 1.213967 & -1.993575 \\ \mathrm{C} & 1.716334 & -1.073962 & 0.306373 \\ \mathrm{H} & 4.928888 & 0.824126 & -0.780628 \\ \mathrm{C} & -1.945639 & -0.390191 & -1.726216 \\ \mathrm{H} & 5.003743 & -0.761799 & 1.125732 \\ \mathrm{C} & -3.069368 & -1.042455 & -1.319210 \\ \mathrm{H} & 2.974741 & -1.964496 & 1.818170 \\ \mathrm{C} & -3.020837 & -1.961267 & -0.243263 \\ \mathrm{H} & 0.432220 & 0.725019 & -2.305649 \\ \mathrm{C} & -1.849270 & -2.200582 & 0.407117 \\ \mathrm{H} & 0.585746 & -2.431928 & 1.513870 \\ \mathrm{C} & 2.864598 & 0.517476 & -1.163803 \\ \mathrm{C} & 4.026624 & 0.300934 & -0.488346 \\ \mathrm{C} & 4.069863 & -0.604989 & 0.600264 \\ \mathrm{C} & 2.947949 & -1.271856 & 0.984802 \\ \mathrm{P} & -0.268517 & 2.434264 & 0.053484 \\ \mathrm{O} & -1.619021 & 2.612007 & -0.526735 \\ \mathrm{~N} & -2.452473 & 0.641304 & 2.197364 \\ \mathrm{~N} & -1.474900 & 1.070325 & 1.858837 \\ \mathrm{~N} & -0.380375 & 1.520694 & 1.529671\end{array}$

$\mathrm{E}=-1119.6067191$

Zero-point correction $=0.213403$

Thermal correction to Energy $=0.229545$

Thermal correction to Enthalpy $=0.230489$

Thermal correction to Gibbs Free Energy $=0.167751$

[DLPNO-CCSD(T)/cc-pVTZ] $=-1118.5098217$

$\mathbf{N}_{2}\left(D_{\infty h}\right)$

$\begin{array}{lllr}\mathrm{N} & 0.000000 & 0.000000 & 0.545035 \\ \mathrm{~N} & 0.000000 & 0.000000 & -0.545035\end{array}$

$\mathrm{E}=-109.4418010$

Zero-point correction $=0.005655$

Thermal correction to Energy $=0.008016$

Thermal correction to Enthalpy $=0.008960$

Thermal correction to Gibbs Free Energy $=-0.012768$

[DLPNO-CCSD(T)/cc-pVTZ] $=-109.3726900$ 
$\operatorname{NPO}\left(C_{\infty \vee v}\right)$

$\begin{array}{lllr}\mathrm{O} & 0.000000 & 0.000000 & -1.423504 \\ \mathrm{P} & 0.000000 & 0.000000 & 0.043840 \\ \mathrm{~N} & 0.000000 & 0.000000 & 1.532728\end{array}$

$\mathrm{E}=-471.0393259$

Zero-point correction $=0.007155$

Thermal correction to Energy $=0.010488$

Thermal correction to Enthalpy $=0.011432$

Thermal correction to Gibbs Free Energy $=-0.015606$

[DLPNO-CCSD $(\mathrm{T}) / \mathrm{cc}-\mathrm{pVTZ}]=-470.6325644$

$C y c-\mathbf{N P O}\left(C_{\mathrm{s}}\right)$

$\begin{array}{lrrr}\mathrm{P} & -0.007902 & 0.671551 & 0.000000 \\ \mathrm{O} & -0.771959 & -0.744000 & 0.000000 \\ \mathrm{~N} & 0.892562 & -0.614677 & 0.000000\end{array}$

$\mathrm{E}=-470.9945224$

Zero-point correction $=0.005717$

Thermal correction to Energy $=0.008920$

Thermal correction to Enthalpy $=0.009864$

Thermal correction to Gibbs Free Energy $=-0.019181$

$[\mathrm{DLPNO}-\mathrm{CCSD}(\mathrm{T}) / \mathrm{cc}-\mathrm{pVTZ}]=-470.5863607$

TS1 $\left(C_{\mathrm{s}}\right)$

$\begin{array}{lrrr}\mathrm{O} & -1.373553 & -1.451997 & 0.000000 \\ \mathrm{P} & -1.280973 & 0.024772 & -0.000000 \\ \mathrm{~N} & 0.005107 & 0.944045 & -0.000000 \\ \mathrm{~N} & 1.632268 & 0.231869 & -0.000000 \\ \mathrm{~N} & 2.709624 & 0.421970 & -0.000000\end{array}$

$\mathrm{E}=-580.4409043$

Zero-point correction $=0.013016$

Thermal correction to Energy $=0.018765$

Thermal correction to Enthalpy $=0.019710$

Thermal correction to Gibbs Free Energy $=-0.018144$

[DLPNO-CCSD(T)/cc-pVTZ] $=-579.9516027$

$v_{\mathrm{i}}=544.7 \mathrm{~cm}^{-1}$

TS2 $\left(C_{1}\right)$

$\begin{array}{lrrr}\mathrm{C} & -0.605143 & -0.922745 & -1.328482 \\ \mathrm{H} & 1.826580 & -1.302166 & 2.512062 \\ \mathrm{C} & 0.476443 & -1.504706 & -0.615955 \\ \mathrm{H} & 3.434727 & -2.855736 & 1.476266 \\ \mathrm{C} & 0.618323 & -1.131237 & 0.741676\end{array}$




$\begin{array}{lrrr}\mathrm{H} & 3.197573 & -3.504942 & -0.897672 \\ \mathrm{C} & -0.296657 & -0.120997 & 1.201415 \\ \mathrm{H} & 1.333300 & -2.621973 & -2.248217 \\ \mathrm{C} & -1.651062 & -0.162934 & 0.710475 \\ \mathrm{H} & -2.646052 & 0.626625 & 2.444493 \\ \mathrm{C} & -1.793614 & -0.547183 & -0.643274 \\ \mathrm{H} & -4.861727 & 0.676525 & 1.365421 \\ \mathrm{C} & 1.706093 & -1.610106 & 1.480309 \\ \mathrm{H} & -5.119350 & -0.003788 & -0.997224 \\ \mathrm{C} & 2.606209 & -2.467699 & 0.896725 \\ \mathrm{H} & -3.159917 & -0.747325 & -2.297536 \\ \mathrm{C} & 2.471704 & -2.836752 & -0.451278 \\ \mathrm{H} & -0.139097 & 0.282339 & 2.197939 \\ \mathrm{C} & 1.434437 & -2.350253 & -1.204037 \\ \mathrm{H} & -0.648646 & -1.057693 & -2.404366 \\ \mathrm{C} & -2.763661 & 0.302205 & 1.417558 \\ \mathrm{C} & -3.996504 & 0.337442 & 0.809370 \\ \mathrm{C} & -4.142841 & -0.047669 & -0.531316 \\ \mathrm{C} & -3.055403 & -0.465592 & -1.256333 \\ \mathrm{P} & 0.344935 & 1.368627 & -0.315355 \\ \mathrm{O} & -0.163070 & 2.750153 & -0.153773 \\ \mathrm{~N} & 3.224949 & 3.386511 & -0.013245 \\ \mathrm{~N} & 2.659348 & 2.418844 & -0.075091 \\ \mathrm{~N} & 2.092164 & 1.336093 & -0.141685\end{array}$

$\mathrm{E}=-1119.5801459$

Zero-point correction $=0.213264$

Thermal correction to Energy $=0.228256$

Thermal correction to Enthalpy $=0.229200$

Thermal correction to Gibbs Free Energy $=0.169786$ [DLPNO-CCSD $(\mathrm{T}) / \mathrm{cc}-\mathrm{pVTZ}]=-1118.4766742$ $v_{\mathrm{i}}=255.5 \mathrm{~cm}^{-1}$

$\operatorname{TS3}\left(C_{1}\right)$

$\begin{array}{lrrr}\mathrm{C} & -0.081584 & -0.369760 & 1.066997 \\ \mathrm{H} & 1.198418 & 2.245304 & -2.409763 \\ \mathrm{C} & 0.753497 & 0.806035 & 0.640863 \\ \mathrm{H} & 2.726727 & 3.641103 & -1.049337 \\ \mathrm{C} & 0.595878 & 1.052584 & -0.730278 \\ \mathrm{H} & 3.008571 & 3.203721 & 1.355752 \\ \mathrm{C} & -0.354725 & 0.061285 & -1.342422 \\ \mathrm{H} & 1.761546 & 1.365373 & 2.452391 \\ \mathrm{C} & -1.677924 & 0.186316 & -0.626819 \\ \mathrm{H} & -3.047061 & 0.645346 & -2.214926 \\ \mathrm{C} & -1.522252 & -0.061640 & 0.742423 \\ \mathrm{H} & -4.998284 & 0.736943 & -0.691410 \\ \mathrm{C} & 1.307581 & 2.062437 & -1.347503 \\ \mathrm{H} & -4.724996 & 0.299499 & 1.714176 \\ \mathrm{C} & 2.169506 & 2.838940 & -0.581340 \\ \mathrm{H} & -2.494405 & -0.236990 & 2.648431\end{array}$




$\begin{array}{lrrr}\mathrm{C} & 2.328597 & 2.592497 & 0.775305 \\ \mathrm{H} & -0.393146 & 0.024754 & -2.426797 \\ \mathrm{C} & 1.626805 & 1.565160 & 1.395987 \\ \mathrm{H} & 0.110870 & -0.777039 & 2.055215 \\ \mathrm{C} & -2.922966 & 0.466911 & -1.153625 \\ \mathrm{C} & -4.015458 & 0.512786 & -0.295544 \\ \mathrm{C} & -3.861286 & 0.265936 & 1.061647 \\ \mathrm{C} & -2.611163 & -0.031519 & 1.591193 \\ \mathrm{P} & 0.210606 & -1.469385 & -0.430037 \\ \mathrm{O} & -0.473429 & -2.764768 & -0.571080 \\ \mathrm{~N} & 1.895865 & -1.554299 & -0.743238 \\ \mathrm{~N} & 2.675975 & -1.800089 & 0.160898 \\ \mathrm{~N} & 3.460714 & -2.011999 & 0.935920\end{array}$

$\mathrm{E}=-1119.6178212$

Zero-point correction $=0.215991$

Thermal correction to Energy $=0.229456$

Thermal correction to Enthalpy $=0.230401$

Thermal correction to Gibbs Free Energy $=0.175806$

[DLPNO-CCSD $(\mathrm{T}) / \mathrm{cc}-\mathrm{pVTZ}]=-1118.5171377$

$v_{\mathrm{i}}=27.7 \mathrm{~cm}^{-1}$

\section{TS4 $\left(C_{1}\right)$}

$\begin{array}{lrrr}\mathrm{C} & -0.112227 & -0.038211 & 1.215788 \\ \mathrm{H} & 1.008857 & 2.245884 & -2.542817 \\ \mathrm{C} & 0.532000 & 1.183133 & 0.650988 \\ \mathrm{H} & 2.098985 & 4.099599 & -1.310262 \\ \mathrm{C} & 0.473507 & 1.201673 & -0.746592 \\ \mathrm{H} & 2.187705 & 4.074124 & 1.150425 \\ \mathrm{C} & -0.220315 & -0.016809 & -1.266562 \\ \mathrm{H} & 1.203235 & 2.191745 & 2.422798 \\ \mathrm{C} & -1.606481 & -0.061604 & -0.664905 \\ \mathrm{H} & -2.889066 & -0.069615 & -2.384161 \\ \mathrm{C} & -1.531305 & -0.117516 & 0.732906 \\ \mathrm{H} & -4.949654 & -0.216299 & -1.017090 \\ \mathrm{C} & 1.042309 & 2.238458 & -1.459530 \\ \mathrm{H} & -4.816991 & -0.338358 & 1.436444 \\ \mathrm{C} & 1.656340 & 3.275385 & -0.764665 \\ \mathrm{H} & -2.616803 & -0.299484 & 2.577841 \\ \mathrm{C} & 1.706267 & 3.260395 & 0.621904 \\ \mathrm{H} & -0.168337 & -0.196078 & -2.336815 \\ \mathrm{C} & 1.149095 & 2.208898 & 1.340904 \\ \mathrm{H} & 0.051776 & -0.251508 & 2.265231 \\ \mathrm{C} & -2.828549 & -0.097746 & -1.303110 \\ \mathrm{C} & -3.982180 & -0.187311 & -0.531102 \\ \mathrm{C} & -3.907972 & -0.257591 & 0.853458 \\ \mathrm{C} & -2.677559 & -0.234614 & 1.498215 \\ \mathrm{P} & 0.454943 & -1.405291 & -0.184229 \\ \mathrm{~N} & 1.798580 & -1.202038 & 0.676959 \\ \mathrm{~N} & 3.169314 & -2.200281 & -0.002997\end{array}$




$\begin{array}{lrrr}\mathrm{N} & 4.147300 & -2.645365 & 0.204880 \\ \mathrm{O} & -0.113839 & -2.718718 & -0.539692\end{array}$

$\mathrm{E}=-1119.5305926$

Zero-point correction $=0.211384$

Thermal correction to Energy $=0.226499$

Thermal correction to Enthalpy $=0.227443$

Thermal correction to Gibbs Free Energy $=0.168476$

[DLPNO-CCSD $(\mathrm{T}) / \mathrm{cc}-\mathrm{pVTZ}]=-1118.4443840$

$v_{\mathrm{i}}=549.1 \mathrm{~cm}^{-1}$

TS5 $\left(C_{\mathrm{s}}\right)$

$\begin{array}{lrrr}\mathrm{C} & -1.165540 & 1.166096 & 0.000000 \\ \mathrm{H} & 0.501466 & -2.293288 & -2.464148 \\ \mathrm{C} & -1.006826 & 0.505994 & -1.230682 \\ \mathrm{H} & -0.449644 & -1.389307 & -4.547632 \\ \mathrm{C} & -0.278184 & -0.708475 & -1.239371 \\ \mathrm{H} & -1.697094 & 0.745316 & -4.542183 \\ \mathrm{C} & 0.342157 & -1.106624 & 0.000000 \\ \mathrm{H} & -2.030829 & 1.976268 & -2.425837 \\ \mathrm{C} & -0.278184 & -0.708475 & 1.239371 \\ \mathrm{H} & 0.501466 & -2.293288 & 2.464148 \\ \mathrm{C} & -1.006826 & 0.505994 & 1.230682 \\ \mathrm{H} & -0.449644 & -1.389307 & 4.547632 \\ \mathrm{C} & -0.072487 & -1.374676 & -2.451542 \\ \mathrm{H} & -1.697094 & 0.745316 & 4.542183 \\ \mathrm{C} & -0.595949 & -0.859588 & -3.614222 \\ \mathrm{H} & -2.030829 & 1.976268 & 2.425837 \\ \mathrm{C} & -1.307887 & 0.350865 & -3.612298 \\ \mathrm{H} & 0.872895 & -2.052930 & 0.000000 \\ \mathrm{C} & -1.498126 & 1.033026 & -2.439912 \\ \mathrm{H} & -1.587851 & 2.165072 & -0.000000 \\ \mathrm{C} & -0.072487 & -1.374676 & 2.451542 \\ \mathrm{C} & -0.595949 & -0.859588 & 3.614222 \\ \mathrm{C} & -1.307887 & 0.350865 & 3.612298 \\ \mathrm{C} & -1.498126 & 1.033026 & 2.439912 \\ \mathrm{P} & 1.954129 & 0.287763 & 0.000000 \\ \mathrm{~N} & 1.474912 & 1.722755 & 0.000000 \\ \mathrm{O} & 3.116665 & -0.635331 & 0.000000\end{array}$

$\mathrm{E}=-1010.1346504$

Zero-point correction $=0.203712$

Thermal correction to Energy $=0.216526$

Thermal correction to Enthalpy $=0.217471$

Thermal correction to Gibbs Free Energy $=0.164146$

[DLPNO-CCSD(T)/cc-pVTZ] $=-1009.1248146$

$v_{\mathrm{i}}=211.3 \mathrm{~cm}^{-1}$

TS6 $\left(C_{\mathrm{s}}\right)$ 


$\begin{array}{lrrr}\mathrm{C} & -0.180912 & 0.312209 & 1.233575 \\ \mathrm{H} & 1.562931 & -1.613192 & -2.486728 \\ \mathrm{C} & 0.795873 & -0.698477 & 0.701126 \\ \mathrm{H} & 2.980901 & -3.208052 & -1.230665 \\ \mathrm{C} & 0.795873 & -0.698477 & -0.701126 \\ \mathrm{H} & 2.980901 & -3.208052 & 1.230665 \\ \mathrm{C} & -0.180912 & 0.312209 & -1.233575 \\ \mathrm{H} & 1.562931 & -1.613192 & 2.486728 \\ \mathrm{C} & 0.178402 & 1.671250 & -0.700630 \\ \mathrm{H} & 0.417677 & 2.840020 & -2.486836 \\ \mathrm{C} & 0.178402 & 1.671250 & 0.700630 \\ \mathrm{H} & 0.919599 & 4.913658 & -1.230566 \\ \mathrm{C} & 1.572917 & -1.602641 & -1.403414 \\ \mathrm{H} & 0.919599 & 4.913658 & 1.230566 \\ \mathrm{C} & 2.362210 & -2.498741 & -0.694948 \\ \mathrm{H} & 0.417677 & 2.840020 & 2.486836 \\ \mathrm{C} & 2.362210 & -2.498741 & 0.694948 \\ \mathrm{H} & -0.425204 & 0.248365 & -2.289099 \\ \mathrm{C} & 1.572917 & -1.602641 & 1.403414 \\ \mathrm{H} & -0.425204 & 0.248365 & 2.289099 \\ \mathrm{C} & 0.432885 & 2.835262 & -1.403635 \\ \mathrm{C} & 0.708555 & 3.996355 & -0.694891 \\ \mathrm{C} & 0.708555 & 3.996355 & 0.694891 \\ \mathrm{C} & 0.432885 & 2.835262 & 1.403635 \\ \mathrm{P} & -1.545739 & -0.041853 & 0.000000 \\ \mathrm{O} & -2.853200 & 0.716460 & 0.000000 \\ \mathrm{~N} & -2.492985 & -1.350654 & 0.000000 \\ \mathrm{~N} & -1.351321 & -3.030332 & 0.000000 \\ \mathrm{~N} & -1.223591 & -4.114209 & 0.000000\end{array}$

$\mathrm{E}=-1119.5332198$

Zero-point correction $=0.211292$

Thermal correction to Energy $=0.226628$

Thermal correction to Enthalpy $=0.227572$

Thermal correction to Gibbs Free Energy $=0.167740$

[DLPNO-CCSD $(\mathrm{T}) / \mathrm{cc}-\mathrm{pVTZ}]=-1118.4517421$

$v_{\mathrm{i}}=302.3 \mathrm{~cm}^{-1}$

$\operatorname{TS} 7\left(C_{1}\right)$

$\begin{array}{lrrr}\text { C } & -0.203514 & 0.172993 & 1.387072 \\ \text { H } & -0.351331 & 2.624823 & -2.452568 \\ \text { C } & -0.395153 & 1.441051 & 0.743357 \\ \text { H } & -0.712745 & 4.741887 & -1.237264 \\ \text { C } & -0.331293 & 1.431390 & -0.664898 \\ \text { H } & -0.826127 & 4.762478 & 1.230765 \\ \text { C } & -0.016298 & 0.144950 & -1.251425 \\ \text { H } & -0.586940 & 2.662614 & 2.505526 \\ \text { C } & -0.649256 & -1.011922 & -0.662773 \\ \text { H } & -0.934608 & -2.186086 & -2.443088\end{array}$




\section{Full Citations for Electronic Structure Codes}

\section{Gaussian 16}

M. J. Frisch, G. W. Trucks, H. B. Schlegel, G. E. Scuseria, M. A. Robb, J. R. Cheeseman, G. Scalmani, V. Barone, G. A. Petersson, H. Nakatsuji, X. Li, M. Caricato, A. V. Marenich, J. Bloino, B. G. Janesko, R. Gomperts, B. Mennucci, H. P. Hratchian, J. V. Ortiz, A. F. Izmaylov, J. L. Sonnenberg, D. WilliamsYoung, F. Ding, F. Lipparini, F. Egidi, J. Goings, B. Peng, A. Petrone, T. Henderson, D. Ranasinghe, V. G. Zakrzewski, J. Gao, N. Rega, G. Zheng, W. Liang, M. Hada, M. Ehara, K. Toyota, R. Fukuda, J. Hasegawa, M. Ishida, T. Nakajima, Y. Honda, O. Kitao, H. Nakai, T. Vreven, K. Throssell, J. A. Montgomery, Jr., J. E. Peralta, F. Ogliaro, M. J. Bearpark, J. J. Heyd, E. N. Brothers, K. N. Kudin, V. N. Staroverov, T. A. Keith, R. Kobayashi, J. Normand, K. Raghavachari, A. P. Rendell, J. C. Burant, S. S. Iyengar, J. Tomasi, M. Cossi, J. M. Millam, M. Klene, C. Adamo, R. Cammi, J. W. Ochterski, R. L. Martin, K. Morokuma, O. Farkas, J. B. Foresman, D. J. Fox, Gaussian 16 Revision C.01, 2016, Gaussian Inc., Wallingford.

\section{Orca 4.2.1}

Neese, F. (2018), Software update: the ORCA program system, version 4.0. WIREs Comput Mol Sci, 8: e1327. https://doi.org/10.1002/wcms.1327.

\section{Chemcraft}

Chemcraft - graphical software for visualization of quantum chemistry computations. https://www.chemcraftprog.com.

\section{IBOView}

G. Knizia, (2013), Intrinsic atomic orbitals: An unbiased bridge between quantum theory and chemical concepts J. Chem. Theory Comput., 9 4834. https://doi.org/10.1021/ct400687b.

Knizia, G. Klein, J.E.M.N. (2015), Electron flow in reaction mechanisms --- revealed from first principles Angew. Chem. Int. Ed., 54, 5518. https://doi.org/10.1002/anie.201410637.

\section{References}

1. Pangborn, A. B.; Giardello, M. A.; Grubbs, R. H.; Rosen, R. K.; Timmers, F. J., Safe and Convenient Procedure for Solvent Purification. Organometallics 1996, 15, 1518-1520.

2. Williams, D. B. G.; Lawton, M., Drying of Organic Solvents: Quantitative Evaluation of the Efficiency of Several Desiccants. J. Org. Chem. 2010, 75, 8351-8354.

3. Transue, W. J.; Velian, A.; Nava, M.; García-Iriepa, C.; Temprado, M.; Cummins, C. C., Mechanism and Scope of Phosphinidene Transfer from Dibenzo-7-phosphanorbornadiene Compounds. J. Am. Chem. Soc. 2017, 139, 10822-10831.

4. Velian, A.; Nava, M.; Temprado, M.; Zhou, Y.; Field, R. W.; Cummins, C. C., A Retro DielsAlder Route to Diphosphorus Chemistry: Molecular Precursor Synthesis, Kinetics of $\mathrm{P}_{2}$ Transfer to 1,3-Dienes, and Detection of $\mathrm{P}_{2}$ by Molecular Beam Mass Spectrometry. J. Am. Chem. Soc. 2014, 136, 13586-13589. 
5. Eckhardt, A. K.; Riu, M.-L. Y.; Müller, P.; Cummins, C. C., Taming Phosphorus Mononitride (PN). Preprint on ChemRxiV 2021, doi:10.33774/chemrxiv-32021-zxtmf.

6. Barybin, M. V.; Diaconescu, P. L.; Cummins, C. C., Coordination Chemistry of a Chelating Amidoximato Ligand. Inorg. Chem. 2001, 40, 2892-2897.

7. Altintas, O.; Glassner, M.; Rodriguez-Emmenegger, C.; Welle, A.; Trouillet, V.; Barner-Kowollik, C., Macromolecular Surface Design: Photopatterning of Functional Stable Nitrile Oxides. Angew. Chem. Int. Ed. 2015, 54, 5777-5783.

8. Fulmer, G. R.; Miller, A. J. M.; Sherden, N. H.; Gottlieb, H. E.; Nudelman, A.; Stoltz, B. M.; Bercaw, J. E.; Goldberg, K. I., NMR Chemical Shifts of Trace Impurities: Common Laboratory Solvents, Organics, and Gases in Deuterated Solvents Relevant to the Organometallic Chemist. Organometallics 2010, 29, 2176-2179.

9. Ammann, C.; Meier, P.; Merbach, A. E., A simple multinuclear NMR thermometer. J. Magn. Reson. 1982, 46, 319-321.

10. Transue, W. J.; Velian, A.; Nava, M.; Martin-Drumel, M.-A.; Womack, C. C.; Jiang, J.; Hou, G.L.; Wang, X.-B.; McCarthy, M. C.; Field, R. W.; Cummins, C. C., A Molecular Precursor to Phosphaethyne and Its Application in Synthesis of the Aromatic 1,2,3,4-Phosphatriazolate Anion. J. Am. Chem. Soc. 2016, 138, 6731-6734.

11. SDBSWeb: http://sdbs.db.aist.go.jp (National Institute of Advanced Industrial Science and Technology, Feb. 01, 2021.

12. Sheldrick, G., SHELXT - Integrated space-group and crystal-structure determination. Acta Crystallogr. A 2015, 71, 3-8.

13. Sheldrick, G., Crystal structure refinement with SHELXL. Acta Crystallogr. C 2015, 71, 3-8.

14. Müller, P., Practical suggestions for better crystal structures. Crystallogr. Rev. 2009, 15, 57-83.

15. van der Sluis, P.; Spek, A. L., BYPASS: an effective method for the refinement of crystal structures containing disordered solvent regions. Acta Crystallogr. A 1990, 46, 194-201.

16. Spek, A., Structure validation in chemical crystallography. Acta Crystallogr. D 2009, 65, 148-155.

17. Adamo, C.; Barone, V., Toward reliable density functional methods without adjustable parameters: The PBE0 model. J. Chem. Phys. 1999, 110, 6158-6170.

18. Dunning, J., Thom H., Gaussian basis sets for use in correlated molecular calculations. I. The atoms boron through neon and hydrogen. J. Chem. Phys. 1989, 90, 1007-1023.

19. Ernzerhof, M.; Scuseria, G. E., Assessment of the Perdew-Burke-Ernzerhof exchange-correlation functional. J. Chem. Phys. 1999, 110, 5029-5036.

20. Grimme, S.; Ehrlich, S.; Goerigk, L., Effect of the Damping Function in Dispersion Corrected Density Functional Theory. J. Comput. Chem. 2011, 32, 1456-1465.

21. Riplinger, C.; Sandhoefer, B.; Hansen, A.; Neese, F., Natural triple excitations in local coupled cluster calculations with pair natural orbitals. J. Chem. Phys. 2013, 139, 134101. 